\title{
Off the Record: The National Security Council, Drone Killings, and Historical Accountability
}

\section{Douglas Cox and Ramzi Kassem $\dagger$}

The central and expanding role of the National Security Council in compiling the "kill list" of U.S. citizens and others approved for drone killing outside of recognized battlefields highlights the largely overlooked fact that, since the mid-1990s, the U.S. government has taken the categorical position that the National Security Council is exempt from both the documentation requirements of the Federal Records Act and the disclosure requirements of the Freedom of Information Act. The current situation undermines long-term processes of accountability for, and transparency about, drone killings, and hinders the role of Congress and the courts in providing a check on executive power. This Article argues that stronger documentation and disclosure requirements are necessary to restore the National Security Council's accountability to Congress, the public, and history.

Introduction ... 364

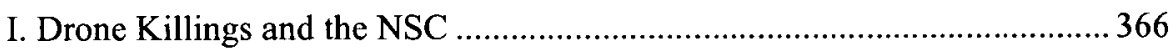

A. Standards Reportedly Governing Drone Killings .........................366

B. Expanding Role of the NSC in Decisions to Kill ............................371

II. The NSC, Federal and Presidential Records, and FOIA ...........................373

A. Federal and Presidential Records ...............................................373

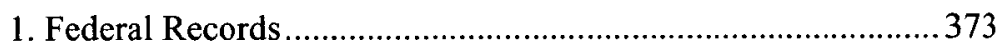

2. Presidential Records .......................................................... 375

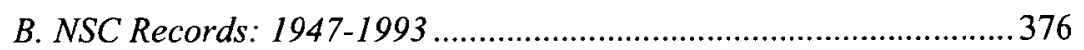

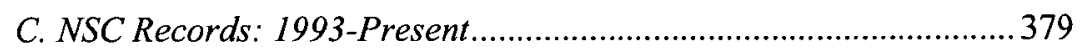

III. Documentation and Accountability for Drone Killings ........................... 383

A. Killing Outside of Recognized Battlefields Requires

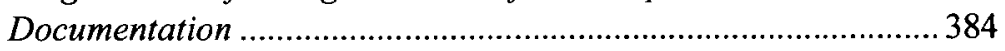

B. The Fallout from Limited Documentation ......................................388

IV. Recommendations for NSC Documentary Accountability ...................... 392

A. Revisiting Judicial Treatment of NSC .......................................... 392

B. Congressional Reassertion of Legislative Intent ........................... 395

C. Executive Branch Reevaluation .................................................. 396 
Introduction

In a speech on May 23, 2013, President Obama defended his administration's drone killing program-in which National Security Council (NSC) officials select U.S. citizens and others for inclusion on a "kill list"and asserted that it was subject to "clear guidelines, oversight and accountability." Just days before this speech, however, the administration moved to dismiss a Freedom of Information Act (FOIA) lawsuit brought by the authors of this Article and their students seeking access to-or at least the preservation of-records documenting the NSC "kill list" determinations to ensure just the kind of oversight and accountability the President cited. ${ }^{2}$ In its filings in the case, the administration not only opposed the disclosure of NSC records, but also expressly asserted that the President has, and should continue to have, unfettered discretion to destroy NSC drone killing records. The President "makes the ultimate decision" to destroy such records, the NSC argued, "and neither the Archivist, nor the Congress, nor the courts may veto that decision." This Article explores the long-term implications of these assertions of executive authority with regard to both transparency and accountability for drone killings.

Part I discusses the publicly available information on the standards governing the drone killing program and the NSC's expansive role in compiling "kill lists" in light of the Constitution and the law of armed conflict. Uncertainty over the legal standards for the drone killing program and a lack of transparency highlight the need for thorough documentation as a prerequisite for meaningful oversight and accountability.

Part II explores the unique history of the NSC's relationship to the Federal Records Act (FRA) ${ }^{4}$ and the FOIA, ${ }^{5}$ on the one hand, and to the Presidential

$\dagger$ Douglas Cox is Associate Law Library Professor, City University of New York School of Law. Ramzi Kassem is Associate Professor of Law, City University of New York School of Law. The authors extend their gratitude to Mark Maher, whose invaluable research assistance greatly advanced this Article's progress. For their wise guidance and thoughtful comments, we also owe thanks to Rebecca Bratspies, Phoebe Clarke, Daniel Herz-Roiphe, Julie Goldscheid, Julie Lim, Andrea McArdle, Ruthann Robson, Franklin Siegel, and the members of CUNY School of Law's Faculty Forum.

1. President Obama, Remarks By the President at the National Defense University (May 23, 2013), http://www.whitehouse.gov/the-press-office/2013/05/23/remarks-president-national-def ense-university [hereinafter President Obama's May 2013 NDU Speech].

2. See Main St. Legal Servs., Inc. v. Nat'l Sec. Council, 962 F. Supp. $2 d 472$ (E.D.N.Y. 2013). In August 2013, the district court granted the NSC's motion to dismiss and held that the NSC was not an agency under the FOIA. The case is currently on appeal at the U.S. Court of Appeals for the Second Circuit.

3. Reply in Support of Defendant's Motion to Dismiss for Failure to State a Claim, Main Street Legal Servs., Inc., 962 F. Supp. 2d 472 (No. 13 Civ. 948), 2013 WL 3094836, at 7.

4. The Federal Records Act (FRA) is a collection of statutes found in Title 44 of the U.S. Code. See discussion infra Subsection II.A.1.

5. 5 U.S.C. $\S 552(2012)$. 
Records Act (PRA), ${ }^{6}$ on the other. Since the early 1990s, the U.S. government has taken the position that the NSC is categorically exempt from both the documentation requirements of the FRA and the disclosure requirements of the FOIA. ${ }^{7}$ Instead, the U.S. government subjects all NSC records to the far less stringent and nearly unenforceable requirements of the PRA. ${ }^{8}$ As a result, there currently may be more exacting legal requirements to create and preserve records documenting the decision to grant or deny Social Security benefits to a U.S. citizen than to record a debate within the NSC about the monumental act of targeting a U.S. citizen outside of a battlefield for a lethal strike using a pilotless aerial drone.

Part III describes the need for more extensive records and the significant consequences of limited documentation and disclosure requirements governing the NSC's role in the drone killing program. The current state of affairs, with diminished transparency and impaired accountability, carries important implications for the expansion of executive power. It undermines the ability to assess, evaluate, and, where appropriate, hold accountable the U.S. government for drone killings. The information vacuum hinders courts adjudicating wrongful death suits by family members of those killed due to the program, current and future government officials deliberating whether to continue the program, Congress evaluating whether to impose limits on the program, and future historians studying the period in U.S. history when senior government officials selected individuals for lethal targeting beyond the borders.

Of course, given recent court decisions, the possibility of meaningful judicial recourse in U.S. courts regarding drone killings appears limited. Judicial avenues of accountability and transparency have proven mostly impassable to those who have sought to learn more about the drone killing program or to impose an outside check on the executive branch's ability to act unilaterally and irreversibly. ${ }^{10}$ Far from trivializing the importance of documentation, these realities further highlight how essential documentation is for future administrations and long-term processes of historical accountability.

Part IV therefore argues that courts should reject the flawed D.C. Circuit ruling that exempted the NSC from the FRA and the FOIA; that Congress

6. 44 U.S.C. $\$ \S 2201-2207$ (2012).

7. See Armstrong v. Exec. Office of the President, 90 F.3d 553, 567 (D.C. Cir. 1996) (finding that the NSC is not subject to either the FRA or the FOIA).

8. Id.

9. While this Article focuses on killings using pilotless and armed aircrafts, or weaponized drones, because that is where much of the ongoing public debate has focused, our arguments apply equally to decisions by the same governmental body to kill persons outside of recognized battlefields using any modality (e.g., surface-to-surface missiles, air-to-surface missiles, seaborne missiles, special operations teams, lone assassins, or other means).

10. See, e.g., Al-Aulaqi v. Panetta, No. 12-1192, 2014 WL 1352452 (D.D.C. Apr. 4, 2014) (dismissing a wrongful death lawsuit seeking damages on behalf of the estates of individuals killed in drone strikes); Al-Aulaqi v. Obama, 727 F. Supp. 2 d 1 (D.D.C. 2010) (dismissing a lawsuit seeking an injunction against the drone killing of plaintiff's son). 
should expressly reassert its original legislative intent that the NSC be subject to both regimes; and that the executive branch should institutionalize robust recordkeeping for the NSC's role in killings outside of recognized battlefields, all in order to ensure a measure of accountability to Congress, the public, and history.

\section{Drone Killings and the NSC}

Statements of senior officials and press reports have cast light on the extensive role of the NSC in the day-to-day coordination of drone killings. Leading-and working as part of-an interagency team, the NSC actively participates in sifting through raw intelligence, vetting lists, and selecting the names of targets for final approval. ${ }^{11}$ The NSC's role, the standards that purport to govern drone killing determinations, and the lack of transparency in the process all illustrate the importance of meaningful documentation.

\section{A. Standards Reportedly Governing Drone Killings}

A U.S. Department of Justice White Paper leaked to the press in February 2013 sets forth "the circumstances in which the U.S. government could use lethal force in a foreign country outside the area of active hostilities against a U.S. citizen who is a senior operational leader of al-Qa'ida or an associated force." $^{12}$

11. See, e.g., John Brennan, Answers to Questions for the Record from Senate Select Committee on Intelligence (Feb. 2013), http://www.intelligence.senate.gov//30207/posthearing.pdf (stating that the "process of deciding" to take the "extraordinary action" of drone killing involves "a discussion among the departments and agencies across our national security team" including "the relevant National Security Council Principals"); The Process Behind Targeted Killing, WASH. POST, Oct. 23, 2012, http://www.washingtonpost.com/world/national-security/the-process-behind-targeted-kill ing/2012/10/23/4420644c-1d26-1 le2-ba31-3083ca97c314_graphic.html (stating that the Deputies Committee of the NSC "culls the rosters" of individuals for targeting); Mark Hosenball, Secret Panel Can Put Americans on "Kill List", REUTERS (Oct. 5, 2011, 7:59 PM), http://www.reuters.com/article/2011/10/05/us-cia-killlist-idUSTRE79475C20111005 (stating that "targeting recommendations are drawn up by a committee of mid-level NSC officials" that are then sent to "the panel of NSC "principals"); Daniel Klaidman, John Brennan, Obama's CIA Chief Nominee, Could Restrain the Agency, NEwSwEEK (Feb. 5, 2013, 12:00 AM), http://www.newsweek.com/john-bre nnan-obamas-cia-chief-nominee-could-restrain-agency-63317 (stating that the NSC's Counterterrorism Security Group "work[s] through individual targeting "nominations").

12. Lawfulness of a Lethal Operation Directed Against a U.S. Citizen Who is a Senior Operational Leader of Al-Qa'ida or An Associated Force, U.S. DEP'T JUST. 1, http://msnbcmedia.msn.com/i/msnbc/sections/news/020413_DOJ_White_Paper.pdf [hereinafter DOJ White Paper]. The legal justification for the killing of Anwar al-Awlaqi, an American citizen, is included in another memorandum. The Second Circuit recently held in a FOIA lawsuit that the government was required to disclose a redacted version of the memorandum. New York Times Co. v. U.S. Dep't of Justice, No. 13-422, 2014 WL 1569514 (2d Cir. Apr. 21, 2014). In addition to the memorandum specifically justifying the killing of al-Awlaqi, President Obama subsequently agreed to disclose eleven classified memoranda to certain members of Congress in the wake of a filibuster of John Brennan's confirmation as Director of the CIA. John Swaine, Drones Overshadow John Brennan's Confirmation as CIA Director, TELEGRAPH, Mar. 8, 2013, http://www.telegraph.co.uk/news/worldnews /us-politics/9916856/Drones-overshadow-John-Brennans-confirmation-as-CIA-director.html. 
The White Paper identifies three conditions for such use of lethal force. First, the targeted individual must pose "an imminent threat of violent attack against the United States;" second, capture must be "infeasible;" and, third, the operation must be "conducted in a manner consistent with applicable law of war principles." 13 A fourth, framing condition articulated by the executive branch requires that the targeted individual be "a senior operational leader," that is to say an al-Qaida (or associated force) leader "actively engaged in planning operations to kill Americans."

According to the Justice Department, the underlying authority for such lethal operations is manifold. The White Paper points to the Constitution and the responsibility it places on the President to protect the country against imminent threats to justify the use of lethal force outside of recognized battlefields. ${ }^{15}$ The government also relies on the right of nations to defend themselves under international law and on the Authorization for Use of Military Force (AUMF), enacted by Congress in 2001. ${ }^{16}$ This authorization empowers the United States to take actions against those organizations that helped carry out the 9/11 attacks. ${ }^{17}$ Because al-Qaida is a non-state actor and employs non-traditional methods of warfare, the administration has interpreted its mandate under the AUMF to authorize unconventional methods of warfare outside of zones of hostilities, including the use of unmanned aerial vehicles. ${ }^{18}$

The executive branch interprets these self-selected limitations broadly, leaving crucial details unclear. For example, the executive branch draws on "a broader concept of imminence," one that "does not require the United States to have clear evidence that a specific attack... will take place in the immediate

13. DOJ White Paper, supra note 12, at 16; see also Eric Holder, Address at Northwestern University School of Law (Mar. 5, 2012), http://www.justice.gov/iso/opa/ag/speeches/201 2/ag-speech-1203051.html [hereinafter Holder Northwestern Speech]. On the issue of the law of armed conflict and drone killings, see generally NiLS MELZER, TARGETED KILLING IN INTERNATIONAL LAW (2008); Laurie R. Blank, After "Top Gun": How Drone Strikes Impact the Law of War, 33 U. PA. J. INT'L L. 675 (2012); and John C. Harwood, Knock, Knock; Who's There? Announcing Targeted Killing Procedures and the Law of Armed Conflict, 40 SYRACUSE J. INT'L L. \& COM. 1 (2012).

14. DOJ White Paper, supra note 12, at 1; see also Charlie Savage, Secret U.S. Memo Made Legal Case to Kill a Citizen, N.Y. TIMES, Oct. 9, 201 1, http://www.nytimes.com/201 1/10/09/world /middleeast/secret-us-memo-made-legal-case-to-kill-a-citizen.html.

15. DOJ White Paper, supra note 12, at 1; see also Jeh C. Johnson, General Counsel, Dep't of Def., Dean's Lecture at Yale Law School, National Security Law, Lawyers and Lawyering in the Obama Administration (Feb. 22, 2012), http://www.lawfareblog.com/2012/02/jeh-johnson-speech-at -yale-law-school [hereinafter Johnson Yale Speech]; Harold H. Koh, Legal Adviser, U.S. Dep't of State, Address to the Annual Meeting of the American Society of International Law: The Obama Administration and International Law (Mar. 25, 2010), http://www.state.gov/s///releases/remarks/13911 9.htm [hereinafter Koh ASIL Speech].

16. Authorization for the Use of Military Force, Pub. L. No. 107-40, 115 Stat. 224 (2001). DOJ White Paper, supra note 12, at 2; see also Johnson Yale Speech, supra note 15; Koh ASIL Speech, supra note 15.

17. See Johnson Yale Speech, supra note 15; Koh ASIL Speech, supra note 15.

18. See Holder Northwestern Speech, supra note 13. On the geographic scope of the "hot" battlefield, see generally Jennifer C. Daskal, The Geography of the Battlefield: A Framework for Detention and Targeting Outside the "Hot" Conflict Zone, 161 U. PA. L. REV. 1165 (2013); and Michael W. Lewis, Drones and the Boundaries of the Battlefield, 47 TEX. INT'L L.J. 293 (2012). 
future." ${ }^{19}$ Moreover, continuous involvement in the planning of attacks can suffice to meet the condition of imminence, as can recent involvement in such planning, in the absence of evidence that the individual has "renounced or abandoned such activities." 20

The feasibility of capture is also interpreted broadly, hinging on such discretionary considerations as whether capture can be effected "during the relevant window of opportunity" and whether capture would pose an "undue risk" to U.S. personnel. ${ }^{21}$ Publicly available examples raise questions about the application of this standard. The decision to kill Anwar al-Awlaki by drone attack rather than attempting to capture him furnishes one such instance. ${ }^{22}$ U.S. intelligence had reportedly tracked al-Awlaki to a specific house in Yemen where he had stayed for an extended period before the strike. ${ }^{23}$ That capture was not attempted in that scenario can be difficult to reconcile with the deployment of U.S. personnel on the ground in Pakistan, without the Pakistani government's knowledge or consent, to storm the compound of Osama bin Laden in an attempt to capture or kill him. ${ }^{24}$

In relation to the law of armed conflict, the White Paper asserts adherence to "the four fundamental law-of-war principles governing the use of force: necessity, distinction, proportionality, and humanity," but precisely how these principles are construed in the context of drone killings is unclear. ${ }^{25}$

In his May 23, 2013 speech, President Obama clarified slightly the executive branch's interpretation of one of those principles, stating that "before any strike is taken, there must be near certainty that no civilians will be killed or injured, the highest standard we can set." 26 Yet crucial questions remain about how that standard is implemented and enforced. Assertions by unnamed U.S. officials that "only members of al-Qaida" were killed in a controversial drone strike on a group of vehicles driving to a wedding in Yemen in December

note 13

19. DOJ White Paper, supra note 12, at 7.

20. Id. at 8 ; see also Savage, supra note 14.

21. DOJ White Paper, supra note 12, at 8; see also Holder Northwestern Speech, supra

22. For a discussion of the targeting of Al-Awlaki, see generally Robert Chesney, Who May be Killed? Anwar al-Awlaki as a Case Study in the International Regulation of Lethal Force, 13 Y.B. INT'L HUM. L. 3 (2010).

23. See Daniel Klaidman, Kill or Capture: THE War on Terror and the Soul OF THE OBAMA PRESIDENCY 263 (2012) (stating that just prior to killing al-Awlaqi, U.S. intelligence had tracked him to al-Jawf province, Yemen, where he had "stayed in the same house for two weeks").

24. Peter Baker et al., Bin Laden is Dead, Obama Says, N.Y. TimES, May 1, 2011, http:/www.nytimes.com/2011/05/02/world/asia/osama-bin-laden-is-killed.html. Another lethal attack reportedly raised concerns with the Department of Defense that lethal targeting rather than attempted capture was chosen to avoid "tangled and politically fraught detention issues." KLAIDMAN, supra note 23, at 126 (noting that Jeh Johnson, General Counsel for the Department of Defense, had "conducted his own inquiry" into whether Saleh Ali Saleh Nabhan had been killed rather than captured in Somalia due to detention concerns).

25. DOJ White Paper, supra note 12, at 8; see Holder Northwestern Speech, supra note

26. President Obama's May 2013 NDU Speech, supra note 1. 
2013 has further raised questions about how the U.S. government makes such assessments. $^{27}$

In a letter to Congress on May 22, 2013, Attorney General Eric Holder also briefly elaborated on the executive branch's understanding of the four lawof-war principles, defining necessity as "the requirement that the target have definite military value"; distinction as "the idea that only military targets may be intentionally targeted"; proportionality as "the notion that the anticipated collateral damage of an action cannot be excessive in relation to the anticipated concrete and direct military advantage"; and humanity as the requirement "to use weapons that will not inflict unnecessary suffering., ${ }^{28}$ But, owing to the dearth of detail on the application of these principles to drone killings, the executive branch's interpretation of these restrictions-and how that understanding compares to that of the public at large or that of the international community-remains largely unknown.

Even the fourth condition-that a targeted individual be a leader in alQaida or an associated force-evades firm grasp. Independent verification that a targeted individual is or was a leader in al-Qaida or an associated force can be quite challenging given the often clandestine nature of such organizations. Moreover, the U.S. government has deemed its list of associated forces with which the United States is presently at war to be classified, withholding it from public view. ${ }^{29}$ One senior U.S. official even questioned under oath whether such a list even existed. ${ }^{30}$ Finally, President Obama called into question whether this remains a limiting factor by omitting any reference to "senior operational leaders" when he addressed drone killings in his May 2013 speech. ${ }^{31}$ A factsheet released by the White House on the same day as that speech also did not confine targeting to senior operational leaders. ${ }^{32}$ To many

27. See Kimberly Dozier, Report: US Drone May Have Killed Dozen Civilians, ASSOCIATED PRESS (Feb. 20, 2014, 9:27 AM), http://bigstory.ap.org/article/report-us-drone-may-have-k illed-dozen-civilians (stating that the U.S. government had conducted two investigations of the drone strike). The statements by U.S. officials were in response to a report by Human Rights Watch that found that "some, if not all, of those killed and wounded were civilians." A Wedding That Became a Funeral: US Drone Attack on Marriage Procession in Yemen, HUM. RTS. WATCH 1 (2014), http://www.hrw.org/sites/default/files/reports/yemen0214_ForUpload_0.pdf.

28. Letter from Eric Holder, Attorney Gen., to Patrick Leahy, Senator (May 22, 2013), http://www.justice.gov/slideshow/AG-letter-5-22-13.pdf [hereinafter Holder May 2013 Letter]; see also Holder Northwestern Speech, supra note 13.

29. See Cora Currier, Who Are We at War With? That's Classified, ProPublica (July 26, 2013, 10:13 AM), http://www.propublica.org/article/who-are-we-at-war-with-thats-classified.

30. Michael Sheehan, Assistant Secretary of Defense for Special Operations and LowIntensity Conflict, stated that he was "not sure there is a list per se." Hearing to Receive Testimony on the Law of Armed Conflict, the Use of Military Force, and the 2001 Authorization for the Use of Military Force Before the S. Comm. on Armed Services, 113 th Cong. 9 (2013).

31. President Obama's May 2013 NDU Speech, supra note 1.

32. Fact Sheet: U.S. Policy Standards and Procedures for the Use of Force in Counterterrorism Operations Outside the United States and Areas of Active Hostilities, WHITE HOUSE 2 (May 23, 2013), http:/www.whitehouse.gov/sites/default/files/uploads/2013.05.23 fact_sheet_on_ppg.pdf (describing the use of lethal force "against a senior operational leader of a terrorist organization or the 
observers, the changes suggested that the U.S. government might be "broadening the potential target set.",33

In his May 2013 speech, President Obama announced that he had signed a Presidential Policy Guidance governing the use of force outside recognized battlefields and codifying "clear guidelines, oversight and accountability." 34 The related White House factsheet also stated that the conditions that had previously applied only to the targeting of U.S. citizens outside of recognized battlefields would henceforth extend to all uses of lethal force "outside the United States and outside areas of active hostilities," irrespective of the targeted individual's nationality. ${ }^{35}$ Where a U.S. citizen was the target, the executive branch would "conduct an additional legal analysis to ensure" compliance with the Constitution and applicable statutes. ${ }^{36}$

Undermining the entire system of procedures for what the U.S. government and many commentators refer to as "targeted" killings, however, is the availability of so-called "signature strikes." This type of lethal U.S. government action outside of recognized battlefields escapes-and, arguably, swallows--the aforementioned criteria. Indeed, "signature strikes" do not target specific, identified individuals who pose a continuing threat, but are based instead on general patterns of behavior observed remotely. ${ }^{37}$

Moreover, recent reports that individuals killed in drone strikes are often located by tracking the "mobile phone a person is believed to be using" rather "than confirming a target's identity with operatives or informants on the ground" also highlight an apparent disconnect between the U.S. government's declared principles and their application. ${ }^{38}$ The risk of error with that approach is elevated owing in part to the frequency with which mobile telephones and numbers can change owners, particularly in the developing world.

Finally, males of "military age" within the same area as a known militant being intentionally targeted are reportedly assumed to be militants themselves, and subject to lawful killing. ${ }^{39}$ As a result, the executive branch does not count

forces that organization is using or intends to use to conduct terrorist attacks") (emphasis added) [hereinafter White House Policy Standards and Procedures].

33. Lesley Clark \& Jonathan W. Landay, Obama Speech Suggests Possible Expansion of Drone Killings, MCCLATCHY DC (May 23, 2013), http://www.mcclatchydc.com/2013/05/23/192081 /obama-promises-anew-to-transfer.html.

34. President Obama's May 2013 NDU Speech, supra note 1.

35. White House Policy Standards and Procedures, supra note 32.

36. Id.

37. Greg Miller, White House Approves Broader Yemen Drone Campaign, WaSH. POST, Apr. 25, 2012, http://www.washingtonpost.com/world/national-security/white-house-approves-br oader-yemen-drone-campaign/2012/04/25/gIQA82U6hT story.html; see also Daniel Klaidman, The Silent Killer, NEwswEEK (Oct. 1, 2012, 1:02 PM), http://www.newsweek.com/drones-silent-killers-64909.

38. Jeremy Scahill \& Glenn Greenwald, The NSA's Secret Role in the U.S. Assassination Program, INTERCEPT (Feb. 10, 2014, 12:03 AM), https://firstlook.org/theintercept/article $12014 / 02 / 10 /$ the-nsas-secret-role.

39. Jo Becker \& Scott Shane, Secret "Kill List" Proves a Test of Obama's Principles and Will, N.Y. TimeS, May 29, 2012, http://www.nytimes.com/2012/05/29/world/obamas-leadership-in 
their deaths as civilian casualties. ${ }^{40}$ This, too, calls into question the U.S. government's compliance with its self-imposed limitations, including the principles of necessity, distinction, and proportionality. ${ }^{41}$

As described above, the criteria publicly articulated by the U.S. government remain amorphous, malleable, and, at times, unclear, affording the executive branch significant discretion and flexibility in targeting and execution. Moreover, those criteria are but the tip of the iceberg. Much of the executive branch's legal rationale for targeting and its application in specific cases remains secret-even when the target is a U.S. citizen. ${ }^{42}$ For example, a legal memorandum issued by the Justice Department's Office of Legal Counsel approving the killing of U.S. citizen Anwar al-Awlaqi was not even shared with Congress until February 2013, despite repeated requests. ${ }^{43}$ The memorandum remains classified and has not been disclosed to the public. ${ }^{44}$ The lack of public information only further underscores the importance of rigorous documentation as a prerequisite to most forms of meaningful accountability.

\section{B. Expanding Role of the NSC in Decisions to Kill}

The footprint of the NSC and the National Security Staff (NSS) in the implementation of drone killing has grown significantly in recent years. The NSC has long had a role in deciding who will ultimately be added to the U.S. government's "kill list," but some of the most crucial decision-making previously took place in interagency meetings chaired by the military. ${ }^{45}$ Indeed, until 2011, a committee led by the chair of the Joint Chiefs of Staff had generally coordinated the process around drone killings outside of recognized

-war-on-al-qaeda.html.

40. Id.

41. The use of signature strikes is in flux apparently due to criticism of the program. Recently, the Obama administration has reportedly ceased to use signature strikes in Pakistan, relying solely on "targeted" strikes of high value targets. Kathy Gannon \& Sebastian Abbot, Criticism Alters US Drone Program in Pakistan, Associated PRESS (July 25, 2013, 1:29 PM), http://bigstory.ap.org/article /criticism-alters-us-drone-program-pakistan.

42. Savage, supra note 14.

43. Charlie Savage, A Not-Quite Confirmation of a Memo Approving Killing, N.Y. TIMES, Mar. 8, 2012, http://www.nytimes.com/2012/03/09/us/a-not-quite-confirmation-of-a-memo-appr oving-killing.html; Krishnadev Calamur, Justice Department to Share Secret Drone Memo With Congress, NAT'L PUB. RADIO (Feb. 6, 2013, 8:28 PM), http://www.npr.org/blogs/thetwo-way/2013/02/0 6/171330145/justice-department-to-share-secret-drone-memo-with-congress.

44. In April 2014, the Second Circuit held that the government must disclose a redacted version of the memorandum in response to a FOIA lawsuit. New York Times Co. v. U.S. Dep't of Justice, No. 13-422, 2014 WL 1569514 (2d Cir. Apr. 21, 2014). The memorandum, however, has not yet been disclosed.

45. Greg Miller, Plan for Hunting Terrorists Signals U.S. Intends to Keep Adding Names to Kill Lists, WASH. POST, Oct. 23, 2012, http://www.washingtonpost.com/world/national-securi ty/plan-for-hunting-terrorists-signals-us-intends-to-keep-adding-names-to-kill-lists/2012/10/23/4789b2a e-18b3-1le2-a55c-39408fbe6a4b_story.html (stating that meetings on targeting had previously been chaired by military representatives). 
battlefields. ${ }^{46}$ That group would hold regular videoconference calls to examine target lists. ${ }^{47}$ Starting in 2011, however, the NSC began pulling those discussions more firmly under its grip. ${ }^{48}$ By 2012 , the White House altogether eliminated the redundancy between the Department of Defense and the NSC in vetting the names on U.S. target lists, favoring the NSC for that role. ${ }^{49}$ Part of the rationale for the shift was that the "process shouldn't be run by those who pull the trigger on the strikes."

Based on statements by senior officials and other sources, lower-level recommendations and analysis from various intelligence agencies and the military are used to generate an initial list of targets for consideration. ${ }^{51}$ The lists are reviewed at regular intervals during mid-level NSC meetings involving representatives from agencies such as the Central Intelligence Agency, the Department of State, and the Joint Special Operations Command. ${ }^{52}$ Targeting recommendations are then sent to the NSC "principals" committee, which includes deputy directors and other senior officials from various civilian, military, and intelligence agencies. ${ }^{53}$

The NSC and its committees appear, therefore, to wield the most control over the final composition of the U.S. government's kill list. The President's role in the process is unclear and, in any event, seems rather limited. ${ }^{54}$ The Justice Department White Paper on killings outside of recognized battlefields, for example, does not on its face require presidential approval, but only authorization "by an informed, high-level official.",55

46. Id.; Karen DeYoung, A CIA Veteran Transforms U.S. Policy, WASH. PosT, Oct, 24, 2012, http:/www.washingtonpost.com/world/national-security/cia-veteran-john-brennan-has-transforme d-us-counterterrorism-policy/2012/10/24/318b8eec-1c7c-11 e2-ad90-ba5920e56eb3_story.html.

47. Miller, supra note 45

48. DeYoung, supra note 46.

49. Miller, supra note 45.

50. Id.

51. For example, the National Counter-Terrorism Center (NCTC), known as the "keeper of the criteria," sifts through U.S. government databases to develop a list of targets that are then submitted to an NSC panel. Miller, supra note 45; see also Klaidman, supra note 11 (stating that the NCTC profiles "potential targets" and the NSC Counterterrorism Security group considers "individual targeting "nominations""). The procedures lower-level military and intelligence officials follow, at least on paper, to compile and analyze targets have been described in some detail. See generally Gregory $\mathrm{S}$. McNeal, Targeted Killing and Accountability, 102 GEO. L.J. 681 (2013).

52. Miller, supra note 45; see also Hosenball, supra note 11.

53. Miller, supra note 45; see also Hosenball, supra note 11 (noting that recommendations from the mid-level NSC panel is sent to NSC "principals").

54. Hosenball, supra note 11 (stating that the NSC "kill" panel "informs the president of its decisions" and that the "role of the president in ordering or ratifying a decision to target a decision is fuzzy"). According to a "former official," one of the reasons for making senior NSC "officials principally responsible for nominating Americans for the target list was to 'protect' the president." Id.

55. DOJ White Paper, supra note 12, at 9. 


\section{The NSC, Federal and Presidential Records, and FOIA}

The central role of the NSC in the drone killing process highlights the complicated relationship between the NSC and federal recordkeeping and disclosure laws. For decades, the NSC complied with both the documentation requirements of the Federal Records Act and the disclosure requirements of the Freedom of Information Act. ${ }^{56}$ In 1994, however, during litigation involving NSC records, the Clinton administration suddenly changed course. It asserted that the NSC was categorically exempt from the FRA and the FOIA, and declared instead that NSC records would, going forward, be subject only to the much less stringent standards of the Presidential Records Act. ${ }^{57}$ In 1996, a sharply divided D.C. Circuit Court of Appeals upheld the Clinton administration's asserted NSC exclusion, which established the current state of affairs, and significantly affected the documentation of NSC deliberations on drone killings. ${ }^{58}$

\section{A. Federal and Presidential Records}

Two distinct regimes govern federal recordkeeping and disclosure: one governs the records of federal agencies, and the other governs presidential records. The two regimes are mutually exclusive; a record may be a federal record or a presidential record, but it cannot be both. ${ }^{59}$ The difference between the two regimes in terms of documentation and disclosure requirements as well as the availability of judicial review is significant.

\section{Federal Records}

The creation, management, and disposition of agency records is governed by a collection of statutes collectively known as the Federal Records Act (FRA). ${ }^{60}$ The disclosure of such federal records, in turn, is governed by the Freedom of Information Act (FOIA). ${ }^{61}$ Together these two statutory regimes create a thorough, and judicially enforceable, framework for federal records.

56. See infra notes 83-87 and accompanying text.

57. Armstrong v. Exec. Office of the President, 877 F. Supp. 690, 694 (D.D.C. 1995).

58. Armstrong v. Exec. Office of the President, 90 F.3d 553 (D.C. Cir. 1996).

59. The Presidential Records Act, for example, expressly excludes from the definition of "presidential records" any "official records of an agency." 44 U.S.C. $\$ 2201$ (2012). The two regimes are not, however, jointly exhaustive in that documents can also be "nonrecords" or personal records. See 36 C.F.R. $\S \S 1222.14,1220.20$ (2013).

60. Relevant statutory provisions derive from the Records Disposal Act of 1943, Pub. L. No. 78-115, 57 Stat. 380 (codified as amended at 44 U.S.C. $\$ \$ 3301-14$ ), the Federal Records Act of 1950, Pub. L. No. 81-754, § 6, 64 Stat. 578 (codified as amended at chapters 21, 25, 27, 29 and 31 of Title 44), and the Federal Records Management Amendments of 1976, Pub. L. No. 94-575, 90 Stat. 2724 (codified as amended at 44 U.S.C. $\$ \$ 2901-2907$ ).

61. 5 U.S.C. $\$ 552(2012)$. 
First, the FRA creates an affirmative duty on agencies to create records by requiring that agencies "shall make and preserve records containing adequate and proper documentation of the organization, functions, policies, decisions, procedures, and essential transactions of the agency" and requiring that those records be "designed to furnish the information necessary to protect the legal and financial rights of the Government and of persons directly affected by the agency's activities." 62 Such a broad statutory duty prevents, in principle, agencies from undertaking significant activities "off the record."

Second, agencies must preserve all federal records that they create and may only destroy them pursuant to schedules of records, which must be approved by the Archivist of the United States, and which provide record retention periods that can range from immediate destruction to permanent preservation. $^{63}$ These disposition schedules are the exclusive method for approving the disposal of federal records. Any destruction of federal records outside this process may therefore violate federal law. ${ }^{64}$

Third, agency records are immediately subject to the disclosure regime of the FOIA pursuant to which agencies are required, subject to exemptions and exceptions, to provide copies of agency records to requesters within twenty working days. ${ }^{65}$ FOIA requests can also have a secondary impact on the record preservation requirements. An agency is required, for example, to retain records requested through the FOIA until the request and any related litigation and appeals are complete, even if the records could have otherwise been destroyed pursuant to an approved records schedule. ${ }^{66}$

Finally, compliance with both the FRA and the FOIA may be subject to extensive judicial review. FOIA expressly provides a right of action to police failures to comply with its mandates. ${ }^{67}$ For the FRA, courts have recognized that individuals whose interests are harmed by an agency's non-compliance have standing to force the agency to fulfill its statutory responsibilities. ${ }^{68}$

62. 44 U.S.C. $\$ 3101$ (2012) (emphasis added).

63. 44 U.S.C. $\S \S 3303-3303$ a (2012); see also NAT'L ARCHIVES \& RECORDS ADMIN., DISPOSITION OF FEDERAL RECORDS: A RECORDS MANAGEMENT HANDBOOK 88-112 (1997) (describing the process for compiling records schedules for temporary and permanent records).

64. 44 U.S.C. $\$ 3314$ (2012) (describing the "exclusive" procedures for submitting records schedules and stating that "records of the United States Government may not be alienated or destroyed except under this chapter").

65. 5 U.S.C. $\$ 552$.

66. Nat'l Archives \& Records Admin., General Records Schedule 14, Item 11, http://www.archives.gov/records-mgmt/grs/grs 14.html (Apr. 2010) (defining retention periods for the "official file copy" of a record requested under the FOIA).

67. 5 U.S.C. $\S 552$.

68. See, e.g., Am. Friends Serv. Comm. v. Webster, 720 F.2d 29, 41 (D.C. Cir. 1983). 


\section{Presidential Records}

In contrast, the creation, management, disposition, and disclosure of presidential records are governed by the Presidential Records Act (PRA), which imposes significantly less strict requirements than the FRA. Under the PRA, the President has near complete authority over presidential records management, including unfettered discretion on the threshold question of whether documents are, or are not, presidential records subject to the PRA. Judicial oversight is extremely limited.

First, on creation, the PRA states that the President "shall take all such steps as may be necessary to assure that the activities, deliberations, decisions, and policies that reflect the performance of his constitutional, statutory, or other official or ceremonial duties are adequately documented." ${ }^{, 69}$ Unlike the corresponding FRA standard, the PRA does not require that this documentation be sufficient to protect the legal rights of individuals affected by government activities. Even more importantly, the D.C. Circuit has held that the President's more limited obligation to document presidential action is not subject to judicial review. $^{70}$

Second, the PRA has significantly less stringent restrictions on the destruction of presidential records than its FRA counterpart. ${ }^{71}$ While the PRA requires that the President seek the "advice" of the Archivist of the United States on the possible destruction of presidential records, such "advice" is nonbinding. ${ }^{72}$ Moreover, and more crucially, the President alone determines whether or not records satisfy the requirements for the definition of "Presidential records" in the first place ${ }^{73}$ That is, the President could exempt

69. 44 U.S.C. $\S 2203(2012)$.

70. See Armstrong v. Exec. Office of the President, 90 F.3d 553, 556 (D.C. Cir. 1996) (noting that while "record-keeping requirements of the FRA are subject to judicial review and enforcement; those of the PRA are not").

71. See id. (noting that while both FRA and PRA "require the preservation of records, the procedures to prevent improper destruction of documents covered by the FRA are significantly more demanding").

72. 44 U.S.C. $\$ 2203$ (c)-(e) (2012); see Armstrong v. Exec. Office of the President, 924 F.2d 282, 290 (D.C. Cir. 1991) ("Although the President must notify the Archivist before disposing of records and the Archivist may inform Congress of the President's desire to dispose of the records, neither the Archivist nor the Congress has the authority to veto the President's disposal decision.").

73. 44 U.S.C. $\$ 2201(2)(2012)$. The General Counsel of the National Archives and Records Administration has noted that the National Archives has "no formal role on the threshold question of whether particular documents or information do or do not constitute 'presidential records' as defined under the PRA." Supplemental Declaration of Gary M. Stern at 3, Citizens for Responsibility \& Ethics in Wash. v. Nat'l Archives \& Records Admin., 583 F. Supp. 2 d 146 (D.D.C. 2008) (No. 07-48). Agencies also have discretion in determining whether agency documents constitute records. See, e.g., 36 C.F.R. $\$ 1222.10$ (2013) (defining documentary material "appropriate for preservation" as federal records as those materials that "in the judgment of the agency should be . . . maintained by an agency"). This power is nevertheless more circumscribed than the President's power in relation to presidential records. First, guidance and direction about what ought to constitute an agency record is both more extensive and more clearly defined. Second, questionable judgments about what constitutes an agency record are, unlike with presidential records, subject to judicial review. See, e.g., Armstrong v. Exec. Office of the President, 1 F.3d 1274, 1283 (D.C. Cir. 1993) (rejecting the government's contention that 
documents from the requirements of the PRA by simply determining that they do not satisfy the definition of "Presidential records."74

Finally, Presidential records are not subject to the mandatory disclosure requirements of the FOIA during a Presidential administration. Access is delayed at least until a President has left office and may be significantly limited long after that time. ${ }^{75}$ Under the PRA, the Archivist of the United States assumes "responsibility for the custody, control, and preservation of, and access to, the Presidential records" when a President leaves office. While the Archivist has an "affirmative," although not clearly defined, "duty to make such records available to the public as rapidly and completely as possible,"76 the records are generally withheld for at least five years after the administration has ended, at which point they can be made available subject to the exemptions and exceptions of the FOIA. ${ }^{77}$ However, for several enumerated categories of information in presidential records, the President can restrict access for up to twelve years. ${ }^{78}$ And, again, even this delayed access applies only to documents that the President has, in his discretion, determined to be "presidential records" subject to the PRA and has elected not to destroy during his administration.

\section{B. NSC Records: 1947-1993}

The relationship between NSC records and the mutually exclusive regimes of federal and presidential records has a complicated history. The NSC was originally created by the National Security Act of 1947 and subsequently became part of the Executive Office of the President during a reorganization in $1949 .{ }^{79}$ Following the passage of the FRA in 1950 and both the original FOIA in 1966 and the FOIA amendments in 1974, the NSC considered itself an "agency" subject to the FRA's documentation requirements and the FOIA's disclosure requirements. This was based on the plain language of the statutory

\footnotetext{
"agency heads have sweeping discretion to decide which documents" constitute records and holding that federal records laws "surely cannot be read to allow the agency by fiat" to declare that "an entire set of substantive e-mail documents" are not records).

74. See 44 U.S.C. $\$ 2201(2)$ (defining "Presidential records").

75. See Armstrong, 90 F.3d at 556 (noting that "the joint regime of the FRA and the FOIA can affect a president's daily operations during his term of office, while the PRA is applicable to a president's papers only after he has left office.").

76. 44 U.S.C. $\S 2203(f)(1)(2012)$.

77. See id. $\S 2204(\mathrm{c})(1)$ (stating that presidential records will generally be "administered in accordance with section 552 of title 5, United States Code" with certain exceptions).

78. See id. $\S 2204$ (a) (listing classified information, trade secrets, and confidential communications "between the President and his advisers" as such categories).

79. National Security Act of 1947, Pub. L. No. 80-253, 61 Stat. 495 (codified as amended in scattered sections of titles 10 and 50 of the U.S. Code); Reorganization Plan No. 4 of 1949, 14 Fed. Reg. 5227, 63 Stat. 1067 (transferring NSC to the Executive Office of the President).
} 
definition of "agency," passed in 1974, which expressly includes establishments within the Executive Office of the President. ${ }^{80}$

The legislative history of the 1974 amendments also supports the conclusion that Congress intended to treat the NSC as an agency. In particular, the House report on the 1974 FOIA amendment expressly stated that the "term 'establishment in the Executive Office of the President,' as used in this amendment, includes such functional entities as . . . the National Security Council." ${ }^{\prime 1}$ Moreover, when the House and Senate versions of the 1974 amendments went to conference, the conference report noted, in a section entitled "Expansion of Agency Definition," that the House version was broader than the Senate version and stated that "the conference substitute follows the House bill.",82

Shortly after the passage of the 1974 definition of "agency," the NSC acknowledged that it was an agency by proposing FOIA regulations "under the authority of" the FOLA. ${ }^{83}$ A month later, the NSC promulgated final FOIA regulations. ${ }^{84}$ The NSC thereafter administered an active FOIA program and was a defendant in multiple FOIA lawsuits in which the NSC accepted that it was subject to the FOIA. ${ }^{85}$

The NSC also complied with the FRA. The NSC submitted a number of record schedules seeking the approval of the Archivist of the United States for

80. 5 U.S.C. $§ 552(f)(1)$ (2012) (defining "agency" to include "an executive department" or "other establishment in the executive branch of the Government (including the Executive Office of the President)").

81. H.R. REP. No. 93-876, at 8 (1974) (emphasis added). The report further added that the intent was to include even entities that might not satisfy the older definition of "agency" under the Administrative Procedure Act, 5 U.S.C. $\$$ 551(1), but which nevertheless "perform governmental functions and control information of interest to the public." Id.

82. H.R. REP. No. 93-1380, at 14 (1974) (Conf. Rep.) (emphasis added).

83. Freedom of Information Fees, 40 Fed. Reg. 3,612 (Jan. 23, 1975).

84. See 32 C.F.R. pt. 2101 (1990) (outlining FOIA processing procedures, fee schedules and declassification and release procedures "to the extent" that FOIA "is applicable to the National Security Council Staff"). The FOIA regulations were initially promulgated in 1975. 40 Fed. Reg. 7,316 (Feb. 19, 1975). Despite the fact that the regulations were withdrawn, a provision remains in the Code of Federal Regulations that relates solely to the NSC FOlA regulations. See 3 C.F.R. $\S 101.4$ (2012) ("Freedom of Information regulations for the National Security Council appear at 32 C.F.R. Ch. XXI."). The NSC also promulgated Privacy Act regulations that remain in force. 32 C.F.R. pt. 2101. This is relevant because the Privacy Act applies only to an "agency" and incorporates the FOIA's definition of agency. See 5 U.S.C. $\S 552 a(a)(1)$ (stating that "the term 'agency' means agency as defined" in the FOIA).

85. See, e.g., Willens v. Nat'l Sec. Council, 726 F. Supp. 325 (D.D.C. 1989) (reviewing a FOIA request for NSC records); Halperin v. Nat'l Sec. Council, 452 F. Supp. 47 (D.D.C. 1978) (same). 
the disposition of its records. ${ }^{86}$ Like other agencies, the NSC transferred older records to the National Archives when they were no longer in current use. ${ }^{87}$

In 1978 , Congress passed the PRA. ${ }^{88}$ As mentioned above, presidential records and agency records are mutually exclusive given that the PRA excludes from its coverage agency records subject to the FOIA. ${ }^{89}$ Contemporaneous with the passage of the PRA, Counsel for the President requested that the Department of Justice's Office of Legal Counsel (OLC) directly address the issue of the status of the NSC as an "agency." The OLC noted that under "conventional standards of statutory interpretation" a court would be "justified" in holding "on the basis of the unambiguous language of the [FOIA]" and the legislative history that the NSC was an agency. ${ }^{90}$ The OLC concluded that "in general" the NSC "is an Agency for [FOIA] purposes.",

While the executive branch uniformly treated the NSC as an agency, there was a limited exception. Given that certain individuals within the NSC might wear "dual hats," in that they might also directly advise the President separate from their NSC duties, a small portion of records that might be held within the NSC could constitute presidential records. ${ }^{92}$ The Supreme Court recognized this limited exception in Kissinger $v$. Reporters Committee for Freedom of the Press, in which the Court determined that records of telephone conversations of Henry Kissinger while he served as National Security Adviser were not subject to the FOIA because the records were created while Kissinger was acting solely in his capacity as a Presidential adviser. ${ }^{93}$ The Supreme Court traced this limited exception back to other language in the legislative history of the 1974 FOIA that indicated that Congress did not intend to include within the definition of "agency" the "President's immediate personal staff or units within the Executive Office [of the President] whose sole function is to advise and

86. Several NSC records schedules from the period during which the NSC was complying with the FRA are available on the National Archives website. Records Control Schedules, NAT'L ARCHIVES, http://www.archives.gov/records-mgmt/rcs/schedules/index.html?dir=/executive-offic e-of-the-president/rg-0273 (last visited Apr. 30, 2014).

87. See Federal Records Guide, Records of the National Security Council, Record Group 273, NAT'L ARCHIVES, http://www.archives.gov/research/guide-fed-records/groups/273.html (last visited Apr. 30, 2014).

88. Pub. L. No. 95-591, 92 Stat. 2523 (codified as amended at 44 U.S.C. $\S \S 2201$ 2207).

89. Id. $\S 2201(2)$ (B). The legislative history of the PRA also indicates that Congress did not intend the PRA to alter the status of any agency, noting that any agency that "is now subject to FOIA would remain so." H.R. REP. No. 95-1487, at 11 (1978).

90. Memorandum of John M. Harmon, Assistant Attorney Gen., Office of Legal Counsel, to Counsel to the President, Freedom of Information Act (5 U.S.C. $§ 552$ ) - National Security Council - Agency Status Under FOIA, 2 Op. O.L.C. 197, 200 (Sept. 6, 1978) [hereinafter Harmon Memo].

91. Id. at 197.

92. See, e.g., Willens v. Nat'l Sec. Council, 726 F. Supp. 325, 325 (D.D.C. 1989) (distinguishing between NSC "institutional files" and "presidential files" in NSC custody).

93. 445 U.S. 136, $156(1980)$. 
assist the President." ${ }^{, 94}$ While recognizing this limited exception, the Supreme Court nevertheless expressly excluded the NSC from it, distinguishing the Kissinger documents, to which the FOIA did not apply, from records of the NSC, which, the Court stated, was "an agency to which the FOIA does apply." 95

The legislative history of the FOIA examined in Kissinger further indicates that Congress intended the exception for entities whose "sole function" is to "advise and assist" the President to be exceedingly narrow. In particular, the conference report indicated that, for entities within the Executive Office of the President, Congress intended the "result reached" in Soucie $v$. David ${ }^{96}$ in which the D.C. Circuit held that the White House Office of Science and Technology (OST) was an "agency." 97 The Soucie court's holding was premised on the existence of a single function of the OST- "to evaluate the scientific research programs of the various federal agencies"-that extended beyond its primary function of advising the President on science and technology policy. ${ }^{98}$ On this basis, the Soucie court found that the OST's "sole function" was not to advise and assist the President. ${ }^{99}$ In finding that the NSC was similarly an agency under the FOIA, the 1978 OLC opinion specifically held that the NSC satisfied the Soucie "sole function" standard. 100

The NSC's compliance with the FRA and the FOIA, however, ended abruptly in the early 1990s when the executive branch unilaterally changed its polices and began categorically treating all NSC records as presidential records.

\section{NSC Records: 1993-Present}

In 1989, journalist Scott Armstrong and other plaintiffs filed suit in Washington, D.C. seeking to prevent the possible destruction of certain records, including records of the NSC, at the conclusion of the Reagan administration.

94. Id. (quoting H.R. REP. No. 93-1380, at 14 (1974) (Conf. Rep.)). A similar distinction was institutionalized within NSC recordkeeping. A former Director of the NSC's Office of Policy and Security Review, for example, noted that NSC documents were "handled on a two-track" system for FOIA purposes. Dep't of Justice, FOIA Focus: Brenda S. Reger, FOIA UPDATE, Vol. VI, No. 1 (1985), http://www.justice.gov/oip/foia_updates/Vol_VI_1/page5.htm. The former Director stated that when the NSC functioned "as White House staff," the "documents generated are presidential records and are eventually placed in the appropriate presidential library," but that when the NSC staff were "included in formulating or implementing NSC directives, the documents generated" were "agency records subject to the FOIA." Id.

95. Kissinger v. Reporters Comm. for Freedom of the Press, 445 U.S. 136, 146 (1980).

96. 448 F.2d 1067 (D.C. Cir. 1971).

97. H.R. REP. NO. 93-1380 (1974) (Conf. Rep.).

98. Soucie, 448 F.2d at 1073-74. Soucie applied the older Administrative Procedures Act definition of "agency." See 5 U.S.C. $\S 551(1)$ (2012) (defining agency as "each authority of the Government of the United States, whether or not it is within or subject to review by another agency").

99. Soucie, 448 F.2d at 1076.

100. See Harmon Memo, supra note 90, at 204 (finding that NSC committees empowered by the President via Executive Order "to act without Presidential participation" were sufficient to "prevent the NSC from being viewed as solely advisory"). 
During the Armstrong $v$. Executive Office of the President litigation, both the district court and D.C. Circuit issued early opinions in the case that were premised on the then-unchallenged conclusion that the NSC was an agency subject to both the FOIA and the FRA. ${ }^{101}$ The last of these opinions was a 1993 decision of the D.C. Circuit that upheld the District Court's finding in Armstrong that the NSC's recordkeeping practices failed to adequately comply with the FRA. ${ }^{102}$

The turning point in Armstrong began with another 1993 D.C. Circuit decision, Meyer v. Bush, in which a divided panel changed the interpretation of the meaning of "agency" under the FOIA in holding that a Presidential Task Force within the Executive Office of the President was not an agency. ${ }^{103}$ Instead of applying the plain language of the FOIA, which expressly includes establishments in the Executive Office of the President within the term "agency," or the limited exception represented by the Soucie "sole function" test, the Meyer court created a new, three-part test. ${ }^{104}$ The Meyer test for determining whether an entity within the Executive Office of the President is an "agency" weighs factors such as whether the entity has a "self-contained structure," its operational proximity to the President, and an assessment of the powers delegated to the entity by the President. ${ }^{105}$ A sharp dissent in Meyer stated that two parts of the new test were "entirely creatures of the majority's own making" and that the test significantly limited the entities within the Executive Office of the President that could count as agencies, contrary to the text of the FOIA. ${ }^{106}$

Following Meyer, the legal adviser to the NSC quietly requested that the OLC revisit the question of whether the NSC was an agency subject to the FOIA. On September 20, 1993, the OLC changed course from its 1978 opinion, and held that, upon "reconsideration of this issue in light of the recent court of appeals decision and our understanding of the current functions of the NSC, we conclude that the NSC is not an agency for FOIA purposes." 107

In reversing its opinion, the OLC expressly noted the substantial change in the interpretation of the FOIA that Meyer had brought about. While the 1978 OLC opinion had held, for example, that the "legislative history of FOIA necessitates a very narrow interpretation of the term "assist"' in the phrase

101. See, e.g., Armstrong v. Exec. Office of the President, 1 F.3d 1274 (D.C. Cir. 1993) (affirming lower court's finding that NSC electronic records were subject to the Federal Records Act); Armstrong v. Exec. Office of the President, 810 F. Supp. 335 (D.D.C. 1993) (finding NSC violations of the Federal Records Act).

102. Armstrong, 1 F.3d. 1274.

103. 981 F.2d 1288 (D.C. Cir. 1993).

104. Id. at 1293.

105. Id.

106. Id. at 1312 (Wald, J., dissenting).

107. Memorandum from Walter Dellinger, Acting Assistant Attorney Gen., Office of Legal Counsel, to Alan J. Kreczko, Special Assistant to the President and Legal Adviser, Nat'l Sec. Council, Re: Status of NSC as an "Agency" Under FOIA (Sept. 20, 1993) [hereinafter Dellinger Memo]. 
"entities whose sole function is to advise or assist the President," the 1993 OLC opinion stated that Meyer had given "the term a much broader meaning." And, therefore, NSC functions that the 1978 OLC opinion had held were "important, substantial and far-reaching governmental functions" illustrating that the NSC did much more than "advise and assist the President" were transformed, postMeyer, into merely "assisting" the President.

Shortly thereafter in the Armstrong v. Executive Office of the President litigation, the executive asserted for the first time in early 1994 that the NSC was not an agency and was subject to neither the FOIA nor the FRA. ${ }^{108}$ District Court Judge Charles R. Richey, in a lengthy February 1995 opinion in Armstrong, rejected the government's arguments that the NSC was not an agency. Judge Richey, scarcely concealing his incredulity, began:

\begin{abstract}
Despite a long history of acting as an "agency," and after admitting it was an agency, and thus subject to the Federal Records Act in this litigation, and notwithstanding a long practice of processing records pursuant to the Freedom of Information Act, the President and the Executive Secretary of the National Security Council suddenly changed course in 1994 declaring that the National Security Council is not an agency and thus not subject to the Federal Records Act. ${ }^{109}$
\end{abstract}

Judge Richey rejected the Executive's assertions and added the further criticism that the government's "sudden change in position" regarding the status of the NSC was "not only contrary to law but without any reasoned explanation." 110

The government appealed. On August 2, 1996, a divided panel of the D.C. Circuit Court of Appeals applied the Meyer three-factor test, reversed the District Court, and held that the NSC was exempt from both the FRA and the FOIA on the basis that the NSC was not an agency. ${ }^{111}$

Writing for the majority, Judge Douglas Ginsburg concluded that, although the NSC had a "self-contained" structure, satisfying the first prong of the Meyer test, ${ }^{112}$ the other two Meyer factors precluded the NSC from being an "agency." First, the Armstrong majority held that not only was the NSC "operationally proximate" to the President under the second Meyer prong, but also that the NSC's proximity should heighten the court's scrutiny of any "functions" of the NSC beyond advising the President, under the third Meyer

108. Armstrong v. Exec. Office of the President, 877 F. Supp. 690, 694 (D.D.C. 1995).

109. Id.

110. Id. at 697

111. Armstrong v. Exec. Office of the President, 90 F.3d 553 (D.C. Cir. 1996).

112. Id. at 559-60 (noting that the NSC staff is a "professional corps" with a significant number of employees and is "organized into a complex system of committees and working groups ... [with] separate offices ... with clearly established lines of authority both among and within the offices"). 
factor. ${ }^{113}$ The finding of "proximity" therefore had the effect of fundamentally altering the Soucie "sole function" standard endorsed in the FOIA's legislative history by placing a thumb on the scale in favor of finding that an entity is not an agency.

The Armstrong majority further departed from the plain language and legislative history of the FOIA when it rejected an extensive list of NSC functions and authorities delegated by Congress or the President that extended beyond advising the President. ${ }^{114}$ The authorities included NSC functions in the areas of intelligence, protection of national security information, telecommunications policy, emergency preparedness, non-proliferation, and public diplomacy. ${ }^{115}$ In rejecting each NSC authority, the Armstrong majority employed a nearly insurmountable standard that required the plaintiff to show not only that the NSC was empowered to exercise a given authority "without the consent of the President," but also that the NSC, as a factual matter, had actually exercised it. ${ }^{116}$

After acknowledging that the President had "delegated to the NSC some authority over emergency preparedness and crisis management," for example, and that the President had instructed "all departments and agencies with responsibility for national defense preparedness to adhere to NSC 'policy and guidelines' in that area," the Armstrong majority nevertheless accepted the NSC's argument that it was merely "providing advice and assistance to the President." In response to the plaintiff's argument that the NSC's role in this area was further established by a presidential directive that authorized the NSC to "oversee the implementation of the goals and principles" in emergency planning, the Armstrong majority stated that the plaintiff was unable to provide evidence that the NSC had provided such oversight and found that this NSC function was not "sufficiently distinct from advising and assisting the President." 118

Finally, the Armstrong majority found that the NSC's past conduct, statements, and compliance with the FOIA and the FRA were "not probative on the question before the court-whether the NSC is indeed an agency within the

113. See id. at 560 (stating that due to NSC's proximity, plaintiffs "must make a strong showing indeed" of non-advisory NSC functions); id. at 567 (stating that, in order to win, plaintiffs' showing of independent authority must be "compelling").

114. Id. at 560-66.

115. $I d$.

116. Id. at 563 (stating that plaintiff had not "established that any of this authority can be exercised without the consent of the President"); $i d$. at 562 (noting that the court is reluctant to place substantial weight on "the mere formality of a delegation of authority"). As the OLC acknowledged in its 1993 opinion, this is a departure from the Soucie "sole function" test in which the relevant issue is the "authority to act." Dellinger Memo, supra note 107, at 7 (noting that the "Soucie test focuses on the authority to act" while the Meyer test "stressed the actual actions of [the] entity in question").

117. Armstrong, 90 F.3d at 563.

118. Id. 
meaning of the FOIA"-noting, "quite simply, the Government's position on that question has changed over the years." 119

Judge David S. Tatel issued a sharply worded dissent stressing that the NSC had "complied with FOIA during the administrations of Presidents Ford, Carter, Reagan, and Bush" and had "declared itself exempt from FOIA only recently while this litigation was pending." In his view, "the record demonstrates that the NSC exercises . . . just the sorts of independent authority that our cases hold satisfy the requirements of the FOIA definition of 'agency.",120

Judge Tatel also stressed that while the President is a member of and receives advice from the NSC, the NSC nevertheless is "a legal entity distinct from the President, and the record indicates that responsibilities delegated to the NSC are in fact carried out without the personal involvement of the President.",121

Finally, Judge Tatel criticized the majority for expanding the limited exclusion from the FOIA and the FRA for specific records created by individuals when they "advise and assist the President": "A host of executive branch activities that Congress subjected to FOIA can also be viewed as activities that 'assist the President,' for surely the President is assisted in executing the laws by every delegation of power he makes." 122 Judge Tatel argued that the D.C. Circuit previously asserted that it "must not allow the 'advise and assist' exception to swallow the FOIA rule" but concluded that "[t]hat is exactly what I fear the court has done today." 123

On the basis of the D.C. Circuit's 1996 Armstrong decision, in June 1998 the NSC removed its regulations for processing FOIA requests. ${ }^{124}$ The White House website currently lists the NSC among entities within the Executive Office of the President that are "exempt from the provisions of the FOIA."125

\section{Documentation and Accountability for Drone Killings}

On the basis of this history, the NSC's significant involvement in substantive targeting determinations results in less stringent legal obligations to document precisely the activity for which documentation requirements ought to be the most exacting: the act of killing without judicial process, be it of a U.S.

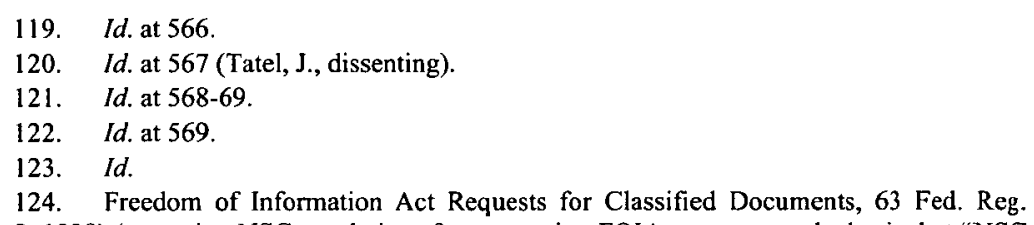
25,736 (May 8, 1998) (removing NSC regulations for processing FOIA requests on the basis that "NSC records are not subject to disclosure under the Freedom of Information Act" and that removal was "consistent" with D.C. Circuit's holding in Armstrong).

125. Office of Administration-FOIA, WHITE HOUSE, http://www.whitehouse.gov/admi nistration/eop/oa/foia (last visited Mar. 1, 2014). 
citizen or of a citizen of another nation, far from a "hot" battlefield, in a country that is not at war with the United States. The current situation severely compromises the possibility of present and future accountability and transparency, while impairing both government decision-making and public debate. Such consequences also carry larger implications for the expansion of executive power.

\section{A. Killing Outside of Recognized Battlefields Requires Documentation}

Current policy regarding U.S. government killings outside of recognized battlefields demands stricter documentation requirements. As described above, the government's current procedures for selecting individuals for drone killings appear to consist of a "funnel" in which agencies first provide lists of individuals along with intelligence information about them. ${ }^{126}$ Those lists are eventually submitted to "a panel of National Security Council officials" that assess and debate the intelligence in light of the relevant, self-selected legal standards and ultimately determine which individuals should be targeted for lethal action. ${ }^{127}$

The government's current exclusion of the NSC from the requirements of the FRA and the FOIA means that while the lower-level agency "inputs" regarding individuals considered for possible targeting remain subject to the FRA and the FOIA, the higher-level, substantive deliberations about those elements within the NSC and the ensuing targeting decisions are not. The nature of NSC deliberations and determinations highlights the compelling need for adequate documentation. ${ }^{128}$

First, the stakes involved are nothing short of existential. As Attorney General Eric Holder noted in his March 2012 speech on targeting U.S. persons, an "individual's interest in making sure that the government does not target him erroneously could not be more significant." 29 The legal requirements for documenting such an extraordinary decision ought, therefore, to be heightened. Other government decisions of analogous gravity are extensively documented.

126. Miller, supra note 45.

127. The extent to which this culled list or part of it is provided to the President for his final approval remains unclear. Hosenball, supra note 11 (stating that the NSC "kill" panel "informs the president of its decisions" and that the "role of the president in ordering or ratifying a decision to target a citizen is fuzzy"); Miller, supra note 45. According to a former official, "one of the reasons for making senior [NSC] officials principally responsible for nominating Americans for the target list was to 'protect' the president." Hosenball, supra note 11.

128. Our focus on record-keeping should not suggest that the Executive's killing program does not bring up serious legal issues. The various constitutional and intemational legal issues implicated by this use of drones have been well reported. See, e.g., Philip Alston, The CIA and Targeted Killings Beyond Borders, 2 HARV. NAT'L SEC. J. 283 (2011); Milena Sterio, The United States' Use of Drones in the War on Terror: The (II)legality of Targeted Killings Under International Law, 45 CASE W. RES. J. INT'L L. 197, 209-12 (2012) (arguing that the administration's use of drones likely violates the law of armed conflict).

129. Holder Northwestern Speech, supra note 13. 
Compare, for example, the documentation of criminal trials that result in the imposition of capital punishment or extended criminal sentences, which include court-reported transcripts for even routine proceedings.

Second, the targeting process that culminates in NSC decision-making is non-adversarial. The government's determinations include no independent advocates for individuals being considered for lethal targeting-advocates who would test and challenge the "evidence" upon which determinations are based. ${ }^{130}$ This increases the need for greater documentation of the deliberations to lay a necessary foundation for any post hoc reviews undertaken to change or discontinue the program, redress erroneous strikes by awarding damages, or inform future policymaking.

Third, the legality of drone killings under both U.S. and international law remains questionable, further underscoring the need for thorough documentation. Whether the unilateral killing of a U.S. citizen outside a zone of hostilities complies with the due process requirements of the U.S. Constitution and with various federal statutes remains an unresolved question. ${ }^{131}$ Similar questions abound regarding the program's conformity with international human rights and humanitarian law. ${ }^{132}$

Indeed, any killings outside of recognized battlefields raise such serious questions. The gravity of these concerns is only compounded when the state

130. While proposals for a so-called "drone court" that would "authorize" drone strikes in advance raise a number of concerns beyond the scope of this Article, were such courts to utilize traditional court reporting, they would offer the ancillary benefit of providing more detailed documentation. See, e.g., Greg Miller, Lawmakers Propose Giving Federal Judges Role in Drone Strikes, but Hurdles Await, WASH. POST, Feb. 8, 2013, http://www.washingtonpost.com/world/national -security/proposal-to-give-federal-judges-a-role-in-drone-strikes-faces-hurdles/2013/02/08/66f53508-72 la-11e2-8b8d-e0b59a1b8e2a story.html; Jeh C. Johnson, Keynote Address at the Center on National Security at Fordham Law School: A "Drone Court": Some Pros and Cons (Mar. 18, 2013), http://www.lawfareblog.com/2013/03/jeh-johnson-speech-on-a-drone-court-some-pros-and-cons; Steve Vladeck, Why a "Drone Court" Won't Work-But (Nominal) Damages Might, LaWfare (Feb. 10, 2013, 5:12 PM), http://www.lawfareblog.com/2013/02/why-a-drone-court-wont-work.

131. See Al-Aulaqi v. Panetta, No. 12-1192, 2014 WL 1352452, at *12 (D.D.C. Apr. 4, 2014) (finding that plaintiff asserted "a 'plausible' procedural and substantive due process claim on behalf of Anwar Al-Aulaqi"); New York Times Co. v. U.S. Dep't of Justice, 915 F. Supp. 2d 508, $515-$ 16 (S.D.N.Y. 2013) (stating that the targeted killings of U.S. citizens seem "on [their] face incompatible with our Constitution and laws"), aff'd in part, rev'd in part, 2014 WL 1569514 (2d Cir. Apr. 21, 2014). John Brennan's 2013 C.I.A. confirmation hearing, for example, was replete with issues relating to the legality of drone strikes. Open Hearing on the Nomination of John O. Brennan To Be Director of the Central Intelligence Agency: A Hearing Before the S. Select Comm. on Intelligence, 113th Cong. (2013), http:/www.intelligence.senate.gov/130207/transcript.pdf; see also Richard Murphy \& Afsheen John Radsan, Due Process and Targeted Killing of Terrorists, 31 CARDOZO L. REV. 405 (2009) (arguing that "American due process principles should control targeted killing of suspected terrorists"); Benjamin McKelvey, Note, Due Process Rights and the Targeted Killing of Suspected Terrorists: The Unconstitutional Scope of Executive Killing Power, 44 VAND. J. TRANSNAT'L L. 1353 (2011) (arguing that "the constitutionality of targeted killing is highly suspect").

132. See generally Alston, supra note 128 (arguing that from the "perspective" of international law "the practice of secret killings conducted outside conventional combat settings" is a "deeply disturbing and regressive one"); Amos N. Guiora, Targeted Killing: When Proportionality Gets All Out of Proportion, 45 CASE W. RES. J. INT'L LAW 235 (2012) (assessing drone killings in the context of law of armed conflict principles such as proportionality and distinction); Sterio, supra note 128, at 209-12 (asserting that "most targeted killings are illegal under international law"). 
actor resorts to so-called "signature strikes" and other approaches that appear to defy the fundamental principles of necessity, proportionality, and distinction and undermine any representation that such strikes are "targeted." 133 Although there is great variation in the reported percentage of drone victims that are nonU.S. citizen civilians, ${ }^{134}$ the very possibility that large numbers of civilians have been killed outside of active zones of hostilities in Pakistan, Yemen, and Somalia only adds moral urgency to these questions and reveals another problematic dimension that limited documentation creates.

Fourth, more rigorous documentation would not create an undue burden on the executive branch. The current targeting process that involves NSC assessments and determinations based upon information about individuals provided by multiple agencies already appears to be, by its nature, highly factand record-intensive, lending itself to documentation. ${ }^{135}$ For instance, the determination that a targeted individual "is a senior operational leader of alQa'ida or an associated force" itself likely requires a complex and fact-bound analysis. ${ }^{136}$ The process also purportedly includes a determination "after a thorough and careful review" that "the individual poses an imminent threat of violent attack against the United States," that "capture is not feasible," and that the lethal force will comply with law of war principles including necessity, distinction, and proportionality. ${ }^{137}$ The description of this "thorough" review, if accurate, highlights the substantive and fact-based determinations required in NSC deliberations. ${ }^{138}$ The extra step of documenting these deliberations in keeping with the FRA would not require a great deal of additional resources. Indeed, such deliberations occur not on a battlefield, but in the controlled confines of a government office building, sometimes over secure videoconference, which could easily be recorded and stored.

Moreover, enhanced documentation of such deliberations should not create additional security concerns. While the FRA fully accounts for the

133. See Klaidman, supra note 37.

134. For an analysis of, and citations to, several studies of civilian casualties and an analysis of their various conclusions, see Ritika Singh, A Meta-Study of Drone Strike Casualties, LAWFARE (July 22, 2013, 4:35 PM), http://www.lawfareblog.com/2013/07/a-meta-study-of-drone-strike -casualties. The administration has contended that the actual number of civilian casualties is minimal and that every effort is taken to reduce civilian casualties. See President Obama's May 2013 NDU Speech, supra note 1 (" $[\mathrm{B}]$ efore any strike is taken, there must be near certainty that no civilians will be killed or injured ...."); see also Holder Northwestern Speech, supra note 13 (stating that using drones "may help to ensure" that "the risk of civilian casualties can be minimized or avoided altogether").

135. Holder Northwestern Speech, supra note 13.

136. DOJ White Paper, supra note 12 , at 1.

137. Holder Northwestern Speech, supra note 13. The current procedure already forces the NSC to analyze data culled from multiple sources. Miller, supra note 45.

138. Although administration officials admit that drone killings have been used outside of recognized battlefields, they consistently aver that the killings target persons who are part of organizations that are at war with the United States. This definition of war, however, strains the traditional definition. See Holder Northwestern Speech, supra note 13 ("Our legal authority is not limited to the battlefields in Afghanistan."); Johnson Yale Speech, supra note 15; Koh ASIL Speech, supra note 15. 
necessity for the emergency destruction of records outside the United States when, for example, "hostile action by a foreign power appears imminent," 139 the records of NSC deliberations that may take place within the White House Situation Room do not present such dangers.

Even if all records are kept in classified form, robust and clear documentation requirements will at least preserve the possibility of accountability down the line. That possibility, however remote in time, becomes especially important when the U.S. government is acting outside of recognized battlegrounds to take the lives of its own citizens and those of citizens of countries that are not at war with the United States. ${ }^{140}$ The domestic rule of law and constitutional concerns could not be more significant and the foreign relations implications more deep and vast, with potential implications for future international conflicts.

Finally, the need for more extensive legal requirements for documentation is made greater by the fact that there are significant disincentives to document this activity. The characteristics of the current process create an incentive for formal and informal policies that attempt to limit the "record," whether by deliberately not creating records or by limiting those that are retained. ${ }^{141}$ This concern is far from theoretical. A study funded by the Pew Charitable Trusts in 2000 concerning former White House Counsels, for example, found that the fear of subpoenas and the perceived inadequacies of presidential privileges had led to "no notes" policies within the White House. Abner Mikva, a former federal judge and White House counsel in the Clinton administration, for instance, stated in an interview that " $[w]$ e just never put anything in writing. At least I did[n't]. All the habits I learned as a good litigator where I took detailed notes about what was going on I threw out the window."142 Even more bluntly, in speaking about his tenure as Chief of Staff in President Gerald Ford's White House, former Vice President Dick Cheney said that he "learned early on that if you don't want your memos to get you in trouble some day, just don't write any.",143

Because the executive does not treat the NSC as a federal agency, the incentive not to create documentation is not counter-balanced by the FRA's

139. 44 U.S.C. $\$ 3311(2012)$.

140. For example, administration officials have noted that the way the United States carries out its drone killing program will constitute an example for the international community. Holder Northwestern Speech, supra note 13 (stating that the "Administration will remain true" to the values of "security, justice and liberty" that have made the United States "a beacon of justice for all the world").

141. See, e.g., Am. Friends Serv. Comm. v. Webster, 720 F.2d 29, 41 (D.C. Cir. 1983) (noting that government entities "have a built-in incentive to dispose of records relating to "mistakes").

142. MaryAnne Borrelli et al., The White House Counsel's Office, THE WHITE HOUSE 2001 PROJECT 32 (2000), http://www.whitehousetransitionproject.org/files/counsel/Counsel-OD.PDF. Charles Ruff, a successor to Mikva, stated: "We did not take notes. We were subject to subpoena. People were very careful not to put things down in writing." Id.

143. Meredith Fuchs, The White House: Off Limits to Historians?, AM. ConstituTION SoC'Y 2 (2008), http://www.acslaw.org/sites/default/files/Fuchs\%20Issue\%20Brief.pdf. 
requirement that agencies "shall make and preserve records" to "furnish the information necessary to protect the legal ... rights of ... persons directly affected by the agency's activities." 144 The U.S. government's current killing policy outside of recognized battlefields therefore demands robust documentation.

\section{B. The Fallout from Limited Documentation}

The current limited documentation requirements undermine the ability to assess, evaluate, and, where appropriate, hold accountable the U.S. government for its decisions to use drone killings. Regardless of the merit of various proposals to ensure proper oversight, the lack of meaningful documentation obligations severely hampers the roles of both the courts and Congress and risks a dangerous expansion of presidential power.

In relation to the courts, the current limited obligation to create and preserve documentation of NSC activities undermines the adequacy of the record. Although the Executive argues that any due process entitlements that targeted U.S. citizens may have are addressed by the unilateral, non-judicial process afforded in internal executive branch deliberations, this position has yet to be tested in court. Should courts ultimately disagree with the Executive's proposition as a matter of constitutional law, it is unclear that they would have an appropriate evidentiary record upon which to proceed.

Courts adjudicating wrongful death suits by family members of citizens or others killed through the drone killing program, for example, might need to review records of targeting determinations-even if under classified seal or ex parte and in camera-in order to properly perform their functicn. A lawsuit filed by the father of Anwar al-Awlaqi (and grandfather of Abdulrahman alAwlaqi) against senior U.S. officials seeking "monetary damages for violating the rights of the deceased under the U.S. Constitution" based on the drone killings of Anwar and Abdulrahman in 2010, provides an illustration. ${ }^{145}$ While the U.S. government has now officially acknowledged killing both individuals, ${ }^{146}$ the circumstances surrounding the approval of the strike that killed Abdulrahman, a sixteen-year-old U.S. citizen, whose death U.S. officials have unofficially admitted was an "outrageous mistake," are unclear, and whether records exist that document that decision is uncertain. ${ }^{147}$

144. 44 U.S.C. $\$ 3101$ (2012).

145. Al-Aulaqi v. Panetta, No. 12-1192, 2014 WL 1352452, at *6 (D.D.C. Apr. 4, 2014). Despite finding that the complaint stated "a 'plausible' procedural and substantive due process claim on behalf of Anwar al-Aulaqi" the court held that there was "no available remedy under U.S. law." Id. at *12.

146. Holder May 2013 Letter, supra note 28, at 2 (officially acknowledging that the United States "specifically targeted and killed" Anwar al-Awlaqi and killed Abdulrahman al-Awlaqi although he was "not specifically targeted").

147. See DeYoung, supra note 46 (quoting a senior U.S. official stating that killing of Abdulrahman was "an outrageous mistake"); Jeremy Scahill, Inside America's Dirty Wars, NATiON, 
Admittedly, the availability of judicial recourse in this arena has thus far been extremely limited. In 2010, for example, the father of Anwar al-Awlaqi filed a pre-strike lawsuit that sought an injunction prohibiting the U.S. government from intentionally killing al-Awlaqi "unless he presents a concrete, specific, and imminent threat to life or physical safety, and there are no means other than lethal force that could reasonably be employed to neutralize the threat." "148 The court, while acknowledging that the issues raised in the case were "extraordinary" and "stark" nevertheless held that al-Awlaqi's father lacked standing and that the "political question" doctrine barred judicial intervention in the case and therefore the court never reached the substance of the case. ${ }^{149}$

Similarly, in a hearing on a motion to dismiss the al-Awlaqi wrongful death suit, the court strongly questioned the government's assertions that there is no role for the judiciary in assessing targeted killings. ${ }^{150}$ The court nevertheless subsequently dismissed the case finding that there was "no available remedy under U.S. law." 151

Despite such unfavorable precedents, judicial oversight and the related need for an adequate record remain relevant. The Second Circuit recently held, for example, that the government must disclose certain records related to drone killings under the FOIA, even if in redacted form. ${ }^{152}$ The district court had previously dismissed the FOIA lawsuit, concluding that it could "find no way around the thicket of laws and precedents" leading to the conclusion that the "[g]overnment has not violated FOIA" by refusing to disclose the requested records, even while noting that drone killings "seem on their face incompatible with our Constitution and laws." 153 On appeal, however, the Second Circuit reversed, in part, finding that the FOIA required disclosure of a legal memorandum on targeted killing. ${ }^{154}$

May 13, 2013, http://www.thenation.com/article/173980/inside-americas-dirty-wars (citing former Obama administration official stating that the killing of Abdulrahman al-Awlaqi "was a mistake, a bad mistake" and quoting NSC spokeswoman refusing to respond stating she "won't go into our internal deliberations").

148. Al-Aulaqi v. Obama, 727 F. Supp. 2d 1, 8 (D.D.C. 2010) (quoting plaintiff's complaint).

149. See id. The government also asserted a military and state secrets privilege, but the court avoided reaching the issue by dismissing the case on other grounds. Id. at 54 .

150. See Scott Shane, Judge Challenges White House Claims on Authority in Drone Killings, N.Y. TIMES, July 20, 2013, at A8 (reporting that the court questioned government lawyers about the limit on targeting of U.S. citizens and that the court provided its own answer: "[t]he limit is the courthouse door").

151. Al-Aulaqi v. Panetta, No. 12-1192, 2014 WL 1352452, at *12 (D.D.C. Apr. 4, 2014).

152. New York Times Co. v. U.S. Dep't of Justice, No. 13-422, 2014 WL 1569514, at *1 (2d Cir. Apr. 21, 2014).

(S.D.N.Y. 2013).

153. New York Times Co. v. U.S. Dep't of Justice, 915 F. Supp. 2d 508, 515-16

154. New York Times Co., 2014 WL 1569514, at *1. 
The Second Circuit decision powerfully illustrates how the FOIA can limit overbroad assertions that records cannot be disclosed by requiring the identification of any "reasonably segregable" information in any given record. ${ }^{155}$ And while the judicial review provided under the FOIA is often deferential to agency determinations, it nevertheless can constitute a meaningful independent check. ${ }^{156}$ Thus, the FOIA offers an established, if imperfect or limited, structure for balancing security imperatives with the need for transparency.

That said, it is the very reality of limited court oversight that makes documentation and record-keeping all the more critical as they are a sine qua non of reliable policy reform and historical accountability. In evaluating whether to impose statutory limits on the drone killing program or to enact specific oversight mechanisms, for example, Congress would need to access documentation on targeting determinations, to the extent possible. ${ }^{157}$

Even within the executive branch, future assessments of whether to continue the program or to take remedial actions in its wake would benefit from the imposition of robust record-keeping requirements. Especially in the case of possible targeting "errors," it would be crucial to be able to review a fully developed "record" to identify, for example, dissenting views that were overlooked or not fully considered or intelligence reports on which too much reliance was placed. Moreover, the success of any after-the-fact assessments of drone killings, even if confined to the executive branch, would depend on the existence of a reliable and fairly comprehensive documentary record. ${ }^{158}$

155. See 5 U.S.C. \$ 552(b) (2012) ("Any reasonably segregable portion of a record shall be provided to any person requesting such record after deletion of the portions which are exempt under the subsection."). Of course, the value of small portions of releasable information in disparate records can itself provide further justification for the government withholding information under the "mosaic theory." See generally David E. Pozen, Note, The Mosaic Theory, National Security, and the Freedom of Information Act, 115 YALE L.J. 628 (2005).

156. In another case involving a different entity within the Executive Office of the President, a district court ordered the disclosure of a record the government argued was classified and exempt under the FOIA. Ctr. for Int'l Envtl. Law v. Office of the U.S. Trade Rep., 845 F. Supp. 2d 252 (D.D.C. 2012). The district court was, however, reversed on appeal. Ctr. for Int'l Envtl. Law v. Office of the U.S. Trade Rep., 718 F.3d 899 (D.C. Cir. 2013).

157. While Senator Dianne Feinstein has asserted that the Senate Intelligence Committee exercises "robust" oversight of the drone killing program including reviewing "strike records (including video footage)" it remains unclear the extent of these records and whether they adequately document the reality of the deliberations that lie behind the drone killing determinations. See Press Release, Feinstein Statement on Intelligence Committee Oversight of Targeted Killings (Feb. 13, 2013), http://www.feinstein.senate.gov/public/index.cfm/press-releases?ID=5b8dbe0c-07b6-4714-b663-b01c7c $9 \mathrm{~b} 99 \mathrm{b8}$. In fact, the asserted oversight of the drone killing program is undermined by the same press release in which Feinstein notes that the executive branch continued to withhold relevant records related to the legal justifications upon which the targeted killing determinations were based. Id.

158. See, e.g., Afsheen John Radsan \& Richard Murphy, Measure Twice, Shoot Once: Higher Care for CIA-Targeted Killing, 2011 U. ILL. L. REV. 1201, 1207 (arguing that there should be a "heightened standard of certainty" for drone targeting and that each killing "should receive an independent review that is as public as national security permits" as well as a "'hard look' review" by an inspector general to ensure that targeted killings "occur only after careful, reasoned consideration of all reasonably available and relevant information"). 
The Executive's asserted categorical exemption of NSC records from the FOIA also significantly impacts the larger, contemporary public debate on such weighty matters. Even in dismissing a FOIA lawsuit for certain records related to targeted killing, for example, a court noted that the disclosure of the requested records would have allowed "for intelligent discussion and assessment of a tactic that (like torture before it) remains hotly debated." 159 While many, if not most, of the NSC records relating to targeted killing may be exempt under FOIA, ${ }^{160}$ recent FOIA cases, including the ACLU's highly successful "Torture FOIA" lawsuit against the Department of Defense and several other agencies in the Southern District of New York, illustrate how a small selection of documents and government Vaughn declarations describing withheld documents (to the extent that the public record allows) can inform public debate and lead to policy changes. ${ }^{161}$

Taking a longer view, limited documentation seriously undermines historical accountability. Future researchers will lack the ability to critically examine the government's present claims if sufficient documentation is not created and preserved. The lack of fulsome records will frustrate the efforts of future historians studying this extraordinary period in U.S. history, when senior government officials were involved in designating individuals for lethal targeting.

Application of the dual regimes of the FRA and the FOIA that previously governed the NSC for almost two decades would go a long way towards addressing concerns relating to documentation and transparency. With respect to documentation, the FRA would heighten the requirement to create documentation that could provide, at the very least, an adequate historical record. Moreover, the FRA's restrictions on the destruction of records, which requires the approval of the Archivist of the United States and is subject to judicial review, would help ensure that records holding continuing value would be preserved.

The current lack of such documentation and disclosure requirements creates risk of expanded presidential power. The broadening of presidential discretion over both what documentation is created as well as what is destroyed

159. New York Times Co. v. U.S. Dep't of Justice, 915 F. Supp. 2d 508, 515 (S.D.N.Y. 2013). The Second Circuit recently reversed, in part, this decision. New York Times Co. v. U.S. Dep't of Justice, No. 13-422, 2014 WL 1569514 (Apr. 21, 2014).

160. See Armstrong v. Exec. Office of the President, 90 F.3d 553, 579 (D.C. Cir. 1996) (Tatel, J., dissenting) (describing the FOIA exemptions relevant to NSC records).

161. See ACLU v. Dep't of Def., 389 F. Supp. 2d 547 (S.D.N.Y. 2005); JACK GOLDSMITH, POWER AND CONSTRAINT 115-17 (2012) (discussing the value of Vaughn declarations in the $A C L U$ v. DOD FOIA case, which "forced the CIA to explain what it refused to produce"). "The Vaughns are often as important as the documents themselves because they can reveal the existence of previously unknown documents (and thus, sometimes, of unknown activities)." Id. at 116-17 (quoting Jameel Jaffer of the ACLU); see also Jack Goldsmith, Drone Stories, the Secrecy System, and Public Accountability, LAWFARE (May 31, 2012, 8:03 AM), http://www.lawfareblog.com/2012/05/drone-storie s-the-secrecy-system-and-public-accountability (stating that Vaughn declarations can "by themselves provide important information" and "can be the basis for further disclosures"). 
or preserved allows presidents greater flexibility of action and an expansion of "presidential deniability," while narrowly limiting any outside scrutiny and oversight, whether in the present or future. ${ }^{162}$ The long, and often infamous, history of the NSC illustrates the gravity of the risks to historical accountability for presidential actions posed by both inadequate documentation and records destruction. Whether President Eisenhower ordered the assassination of a foreign leader during an NSC meeting, for example, was intentionally omitted from NSC minutes, ${ }^{163}$ while NSC records potentially illustrating more extensive knowledge on the part of President Reagan of the Iran-Contra affair were famously destroyed. ${ }^{164}$ By excluding the NSC from both the FOIA and the FRA, the D.C. Circuit's decision in Armstrong essentially institutionalized the President's ability to avoid accountability.

\section{Recommendations for NSC Documentary Accountability}

The consequences flowing from the NSC's central role in drone killing determinations provide a compelling, and urgent, argument for revisiting the U.S. government's treatment of the NSC as exempt from both the FRA and the FOIA. Possible solutions could come from the courts, Congress, or the executive branch.

\section{A. Revisiting Judicial Treatment of NSC}

The first possible remedy would be for courts to revisit the D.C. Circuit's exclusion of the NSC from the FOIA and the FRA in Armstrong. ${ }^{165}$ By reaffirming the NSC's obligation to comply with the FRA and the FOIA, the courts could not only restore recordkeeping, preservation, and disclosure obligations, but also ensure judicial oversight of the NSC's compliance with those requirements. ${ }^{166}$ This is especially significant in the context of drone killings over which the judiciary has thus far exercised limited oversight. ${ }^{167}$

162. See, e.g., Heidi Kitrosser, It Came From Beneath the Twilight Zone: Wiretapping and Article II Imperialism, 88 TEX. L. REV. 1401, 1420 (2010) (discussing examples of record destruction for the purposes of creating deniability for the President).

163. See Athan G. Theoharis, In-House Cover-up: Researching FBI Files, in BEYOND THE HISS CASE: THE FBI, CONGRESS AND THE COLD WAR 20, 41 (Athan G. Theoharis ed., 1982) (surveying historical Congressional testimony indicating the "intentional incompleteness of NSC minutes" and discussing President Dwight Eisenhower's order to assassinate Congolese leader Patrice Lumumba).

164. See, e.g., Linda P. Campbell, North: Poindexter Destroyed Paper, CHI. TRIB., Mar. 13, 1990, http://articles.chicagotribune.com/1990-03-13/news/9001210334_1_iran-contra-poindext er-district-judge-harold-greene ("Oliver North said Monday he watched former National Security Adviser John Poindexter destroy a politically damaging document signed by then-President Ronald Reagan.”).

165. See Armstrong, 90 F.3d 553.

166. See discussion supra notes 67-68 and accompanying text.

167. See, e.g., Al-Aulaqi v. Panetta, No. 12-1192, 2014 WL 1352452 (D.D.C. Apr. 4, 2014) (dismissing wrongful death lawsuit seeking damages on behalf of the estates of individuals killed 
Judicial authority even over the limited area of enforcing FOIA obligations could also result in more transparency that could further inform public debate over drone killings.

While Armstrong has become increasingly entrenched within the D.C. Circuit, ${ }^{168}$ the decision has several shortcomings. First, as described above, the Armstrong decision significantly departed from the plain language of the FOIA statute, which unambiguously includes establishments in the Executive Office of the President within the definition of "agency," and fundamentally altered the "sole factor" test applied in Soucie, which was endorsed in the FOIA's legislative history. ${ }^{169}$

Further, the NSC's assertion that it is not an agency subject to the FOIA has not been widely challenged outside of the D.C. Circuit. ${ }^{170}$ Courts unencumbered by Armstrong may find the D.C. Circuit's analysis unpersuasive, particularly given that Armstrong relied upon standards derived from earlier precedent unique to the D.C. Circuit. ${ }^{171}$ The analysis in Armstrong further distances the law of that circuit from the statutory language and relevant Supreme Court precedent that would control in other circuits. ${ }^{172}$ If another circuit were to conclude that Armstrong was wrongly decided, it could increase the likelihood of the Supreme Court granting certiorari to revisit - and perhaps reaffirm-its earlier precedent indicating that the NSC was subject to the FOIA. ${ }^{173}$

Moreover, even in the context of D.C. Circuit jurisprudence, the analysis in Armstrong is demonstrably outdated. The Armstrong majority's analysis relied upon a detailed factual examination of NSC legal authorities delegated by Congress or the President in order to determine whether the NSC was exercising substantial independent authority. This analysis, however, was

in drone strikes); Al-Aulaqi v. Obama, 727 F. Supp. 2d 1 (D.D.C. 2010) (dismissing a lawsuit seeking an injunction against the drone killing of the plaintiff's son); but see New York Times Co. v. U.S. Dep't of Justice, No. 13-422, 2014 WL 1569514, at*1 (2d Cir. Apr. 21, 2014) (holding that the government was required under the FOIA to disclose a legal memorandum justifying targeted killing).

168. See, e.g., Citizens for Responsibility \& Ethics in Washington v. Office of Admin., 566 F.3d 219 (D.C. Cir. 2009) (relying upon Armstrong in holding that the Office of Administration within the Executive Office of the President is not subject to the FOIA); Elec. Privacy Inform. Ctr. v. Nat'l Sec. Agency, 795 F. Supp. 2d 85 (D.D.C. 2011) (relying on Armstrong in holding that the NSC need not review records referred to the NSC by the National Security Agency following a FOIA request).

169. See supra notes 103-111 and accompanying text.

170. The authors' challenge to Armstrong is currently pending in the Second Circuit.

171. See Meyer v. Bush, 981 F.2d 1288 (D.C. Cir. 1993) (holding that a Presidential Task Force did not constitute an agency under the FOIA and establishing a new three-part test for agency status).

172. The statutory language is clear and the most relevant Supreme Court decision to the issue cites language in the legislative history also suggesting that the NSC is subject to the FOIA. Kissinger v. Reporters Comm. for Freedom of the Press, 445 U.S. 136, 156 (1980) (citing Congressional documents "indicating that the National Security Council is an executive agency to which the FOIA applies").

173. See id. 
confined to the NSC authorities at the time of the August 1996 decision in Armstrong. The scope of the NSC's authorities has changed materially since then.

For example, two months after the Armstrong decision, Congress amended the statutory authorities of the NSC by creating within the NSC the Committee on Foreign Intelligence and the Committee on Transnational Threats. Congress empowered these NSC entities with authorities that extend far beyond merely advising and assisting the President. ${ }^{174}$ In 2008 , for example, the Senate Select Committee on Intelligence found that the NSC's Committee on Foreign Intelligence had authorized intelligence activities based on the NSC Committee's "broad authority to identify intelligence needs, establish priorities to meet those intelligence needs, and establish policies relating to the conduct of intelligence activities of the United States 'including appropriate roles and missions for the elements of the intelligence community and appropriate targets of intelligence collection activities." 175 The Senate Committee explicitly noted that these independent NSC Committee authorities were "in addition to "performing such other functions as the President may direct.", "176

The NSC's activities in recent years further illustrate expansions in substantive authority that go beyond simply advising the President. For example, according to declarations by senior administration officials, the NSC created the Special Access Program governing the CIA's rendition, detention, and interrogation program that involves the use of torture and other brutal interrogation techniques. ${ }^{177}$ The NSC also currently supervises the High-Value

174. Moreover, given that the D.C. Circuit's analysis in Armstrong focused on the NSC's independence from the President, it is particularly relevant that Congress created these committees within the NSC in 1996 over the objection of the President. See Presidential Statement on Signing the Intelligence Authorization Act for Fiscal Year 1997, 2 PUB. PAPERS 1813 (Oct. 11, 1996) ("Although I am signing this Act, I have concerns about the provisions in it that purport to direct the creation of two new National Security Council (NSC) committees-a Committee on Foreign Intelligence and a Committee on Transnational Threats.").

175. S. SELECT COMM. ON INTELLIGENCE, INTELLIGENCE ACTIVITIES RELATING TO IraQ Conducted by the Policy Counterterrorism Evaluation Group and the OfFice of

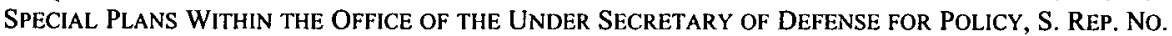
110-346, at 9 (2008) (quoting section 101(h) of the National Security Act of 1947).

(1947)) (emphasis added).

176. Id. (quoting National Security Act of 1947, Pub. L. 80-253, $\S 101($ b), 61 Stat. 495

177. Director of the CIA Leon E. Panetta stated in a sworn declaration that

Officials of the National Security Council (NSC) determined that in light of the extraordinary circumstances affecting the vital interests of the United States and the sensitivity of the activities contemplated in the CIA terrorist detention and interrogation program it was essential to limit access to the information in the program. NSC officials established a special access program governing access to information relating to the CIA terrorist detention and interrogation program. As the executive agent for implementing the terrorist detention and interrogation program, the $\mathrm{ClA}$ is responsible for limiting access to such information in accordance with the NSC's direction.

Declaration of Leon E. Panetta, Director, CIA, at \$ 30, ACLU v. Dep't of Def., 723 F. Supp. 2 d 621 (S.D.N.Y. 2010) (No. 04-cv-4151) (emphasis added). In one of his first acts in office, President Obama 
Detainee Interrogation Group (HIG). ${ }^{178}$ Finally, the NSC's central and expanding role in the targeted killing process itself provides a compelling argument that NSC exercises substantial independent authority.

\section{B. Congressional Reassertion of Legislative Intent}

In addition, or alternatively (should courts prove unwilling to revisit Armstrong), Congress could affirmatively reassert its legislative intent. Shortly after Armstrong, members of Congress criticized the ruling as being contrary to legislative intent. ${ }^{179}$ Congress has not, however, revisited the FOIA's definition of agency to make the inclusion of the NSC more express' to avoid further misinterpretation.

An explicit reassertion of congressional authority over the status of the NSC under the FOIA and the FRA would present a number of benefits. First, doing so would allow Congress to ensure its own ability to provide meaningful oversight of the drone killing program (and other NSC activities). Controversies last year over the President's refusal to provide members of Congress with copies of legal opinions authorizing certain drone strikes

ordered the closure of CIA "detention facilities," forbidding the agency from operating prisons again. Exec. Order No. 13,491, 74 Fed. Reg. 4893 (Jan. 22, 2009). An often-overlooked provision, however, exempts "short-term, transitory" facilities from the order. $I d . \S 2(\mathrm{~g})$. And, in a statement regarding C.I.A. detention, Senator Dianne Feinstein lamented as "terrible mistakes" only "long-term, clandestine 'black sites."' Press Release, Feinstein Statement on CIA Detention, Interrogation Report (Dec. 13, 2012), http://www.feinstein.senate.gov/public/index.cfm/press-releases?ID=46c0b685-a392-4400-a9a3 $-5 \mathrm{e} 058 \mathrm{~d} 29 \mathrm{e} 635$ (emphasis added). The effect of these distinctions is to preserve the CIA's ability to hold prisoners directly, albeit only for a short term. While President Obama in the same executive order also limited interrogation techniques to those listed in the Army Field Manual, that document was modified in 2006 to permit stress positions, sleep deprivation, and isolation-methods potentially amounting to torture. See, e.g., The U.S. Army Field Manual on Interrogation: A Strong Document in Need of Careful Revision, HUM. RTS. FIRST, http://www.humanrightsfirst.org/wp-content/uploads/pdf/Army_Field_Ma nual.pdf (last visited Apr. 30, 2014). The controversial CIA program, then, retains some vitality despite popular perception and official statements to the contrary.

178. See DoD Support to the High-Value Detainee Interrogation Group (HIG), No. 3115.13, U.S. DEP'T DEF. 1 (Dec. 9, 2010), http://www.dtic.mil/whs/directives/corres/pdf/311513p.pdf (stating that its purpose is to assign responsibilities "in accordance with the National Security Council 'Charter for Operations of Interagency High-Value Detainee Interrogation Group'"); Press Release, U.S. Dep't of Justice, Special Task Force on Interrogations and Transfer Policies Issues Its Recommendations to the President (Aug. 24, 2009), http://www.justice.gov/opa/pr/2009/August/09-ag-835.html (recommending the creation of HIG and that it be subject to "policy guidance and oversight coordinated by the National Security Council"). The NSC's Charter for the group is dated April 19, 2010, but is not publicly available. Id. at 3; see also Mark Benjamin, Special Group Quietly Assists in Terrorist Interrogations Under Obama, TIME, May 16, 2011 (stating that HIG is "reporting to the National Security Council"); Anne E. Kornblut, New Unit to Question Key Terror Suspects, WASH. PosT, Aug. 24, 2009, http://www.washingtonpost.com/wp-dyn/content/article/2009/08/23/AR2009082302598.html (stating that President Obama had approved the creation of HIG and that it would be "overseen by the National Security Council").

179. See 142 CONG. REC. S10,716 (daily ed. Sept. 17, 1996) (statement of Sen. Patrick Leahy) (stating that the D.C. Circuit excluded the NSC from FOIA "despite the fact that the NSC has complied with FOIA for years under both Republican and Democratic Presidents"); id. at H10,451 (statement of Rep. Carolyn Maloney) (stating that Armstrong decision was "contrary to 20 years of freedom of information practice and contrary to the way Congress has treated the National Security Council in other legislation"). 
highlighted the limitations of congressional oversight and the contentious line between presidential and congressional authority. ${ }^{180}$ The administration's treatment of all NSC records related to drone killings as "presidential records" that can be destroyed at the President's discretion constitutes an assertion of presidential power that Congress is empowered to curb by reasserting its original statutory intent.

Second, a clear statutory amendment would have the benefit of precluding future circuit splits while allowing Congress the ability to address methodically the unique nature of the NSC and to ensure consistency with other relevant statutory regimes, such as the PRA. ${ }^{181}$

Finally, an express amendment to reassert legislative intent would provide a meaningful check on the D.C. Circuit's application of the law to entities beyond the NSC. In particular, the text of the FOIA unambiguously includes the Executive Office of the President in the definition of an "agency" subject to the FOIA. ${ }^{182}$ Yet, under the D.C. Circuit's interpretation of that statute over the past two decades, less than half of the entities within the Executive Office of the President are currently subject to the FOIA. ${ }^{183}$

\section{Executive Branch Reevaluation}

In addition to-or in the absence of-action by the courts or Congress, the Executive should clarify what documentation is presently created regarding its drone killings program and should both preserve past records and commit to robust record-keeping going forward. Speeches by the President and senior NSC officials who have been involved in the drone-killing program have repeatedly sought to assure the public of the thorough and careful nature of deliberations surrounding U.S. government killings outside of recognized battlefields. ${ }^{184}$ Such statements ought to be supported by thorough and detailed

180. See, e.g., Scott Shane \& Mark Mazzetti, White House Tactic for C.I.A. Bid Holds Back Drone Memos, N.Y. TIMES, Feb. 20, 2013, http://www.nytimes.com/2013/02/21/us/politics/strateg y-seeks-to-ensure-bid-of-brennan-for-cia.html.

181. Congress could clarify, for example, the line between federal records and presidential records. One option would be for Congress to codify the distinction the NSC itself made during the decades it complied with the FOIA between NSC's "institutional files," which were subject to the FOIA, and "presidential files" in its custody. See supra notes 92-94 and accompanying text.

182. See 5 U.S.C. $\$ 552(f)(1)(2012)$ (defining "agency" to include an "establishment in the executive branch of the Government (including the Executive Office of the President)") (emphasis added). The NSC has been part of the Executive Office of the President since 1949. Reorganization Plan No. 4 of 1949, 14 Fed. Reg. 5227, 63 Stat. 1067.

183. Office of Administration-FOIA, supra note 125 (stating that Executive Office of the President entities that are "exempt from the provisions of the FOIA" include the Office of Administration, the White House Office, the Office of the Vice President, the Council of Economic Advisers, the National Security Council, the Office of Policy Development, and the President's Foreign Intelligence Advisory Board).

184. See, e.g., President Obama's May 2013 NDU Speech, supra note 1 (stating that the drone killing process was subject to "clear guidelines, oversight and accountability"); Holder May 2013 Letter, supra note 28, at 3-4 (stating that targeting decisions are "subjected to an exceptionally 
documentation that could provide verification, at least in the eyes of successor officials, pending declassification of those records in due time.

It is an extraordinarily grave matter for senior U.S. government officials to sit on NSC committees that decide which individuals, including U.S. citizens, will be killed. In that setting, it is difficult to see why documentation ought to be less thorough than the court-reported transcripts created for even routine federal court hearings.

Moreover, extensive documentation of such decisions is arguably what would be required of a reasonable reading of the PRA, which mandates that "the President shall take all such steps as may be necessary to assure that the activities, deliberations, decisions, and policies that reflect the performance of his constitutional, statutory, or other official or ceremonial duties are adequately documented." 185 It remains unclear whether current documentation practices focusing on the NSC's involvement in the drone killing program satisfy this modest standard.

The President and senior officials have repeatedly promised greater transparency on drone killings. Meaningful discretionary transparency from the Executive, however, has been inadequate, both in perception and in reality. The leaked White Paper, ${ }^{186}$ for example, provided an unprecedented measure of transparency, but it also raised questions about why it had been deemed initially necessary to withhold many of the details that the document disclosed. $^{187}$

While the NSC would presumably never voluntarily submit to the FOIA, the Executive ought to recognize that the burden might be comparatively low and the value comparatively high. The NSC created a discretionary, quasiFOIA program in $1998,{ }^{188}$ for example, which replicated at least a portion of the burden and complexities of searching and reviewing NSC records that the FOIA would require. Moreover, as Judge Tatel noted in his dissent in Armstrong, many NSC documents would not be disclosed under the FOIA because they would likely fall within one of the standard FOIA exemptions and therefore "applying FOIA to the NSC presents little risk of improper intrusion

rigorous interagency legal review" and "extensive policy review at the highest levels of the U.S. government").

185. 44 U.S.C. $§ 2203$ (a) (2012). As mentioned above, the power of the President includes the ability to determine whether documents constitute presidential records, and therefore whether the PRA applies at all. See supra notes 73-74 and accompanying text.

186. See DOJ White Paper, supra note 12.

187. In addition, disclosures of information regarding the legal authorization for drone killings was first withheld from members of Congress and then made available in piecemeal fashion that suggested the disclosures were being tied to ongoing confirmation hearings. See, e.g., Swaine, supra note 12 .

188. See Procedures for Obtaining Access to National Security Council (NSC) Records, 63 Fed. Reg. 25,737 (May 8, 1998) (providing "procedures for obtaining access to National Security Council (NSC) records"). 
into the President's exercise of his constitutional responsibilities." 189 At the same time, the FOIA would ensure that disclosures were as broad as security considerations would permit in furtherance of the same transparency the President and other senior officials have promised.

Indeed, the problem with the NSC's voluntary record disclosures is precisely that they are discretionary and not subject to the very judicial review that - while carrying some risk that unwanted disclosure could be compelledalso provides legitimacy and enforces a level of transparency by ensuring that all "reasonably segregable" and releasable information is disclosed. ${ }^{190}$ That is, the application of the FOIA could provide the Executive with a way to illustrate that its promises of greater transparency are meaningful.

Relevant to both documentation and reasonable transparency of the drone killing program is the President's May 2013 announcement that the "playbook" for drone killing, which had been discussed at length in news reports based on unofficial accounts sourced to unnamed officials, had been committed to official form in "Presidential policy guidance." 191 This "playbook" supposedly bureaucratizes the drone killing process and may provide detailed guidance on the documentation created and preserved to ensure long-term accountability for drone killing. It is, unfortunately, not public, has not been voluntarily disclosed, and is, according to the executive branch, immune to the FOIA.

\section{Conclusion}

The role of the NSC in drone killings is to debate and decide whether individuals, including U.S. citizens, will be killed in U.S. strikes outside of recognized battlefields. To describe such decisions as among the most controversial and significant that the government makes is far from hyperbole. According to unofficial accounts of such NSC meetings, moreover, debate over the facts, the law, and broader policy has been extensive and sometimes fierce. One example can be found in the publicly available description of a 2010 conference call initiated by NSC Legal Counsel Mary DeRosa to "nail down final approval" for the drone targeting of Sheikh Mukhtar Robow, an alleged leader within the al-Shabab organization in Somalia. ${ }^{192}$ Department of Defense General Counsel Jeh Johnson reportedly stated that he believed that Robow could be lawfully targeted. ${ }^{193}$ State Department Legal Adviser Harold Koh,

dissenting).

189. Armstrong v. Exec. Office of the President, 90 F.3d 553, 579 (1996) (Tatel, J.,

190. 5 U.S.C. $\$ 552$ (b) (2012).

191. President Obama's May 2013 NDU Speech, supra note 1 ("[O]ver the last 4 years, my administration has worked vigorously to establish a framework that governs our use of force against terrorists-insisting upon clear guidelines, oversight, and accountability - that is now codified in a Presidential policy guidance that I signed yesterday.").

192. See, e.g., KLAIDMAN, supra note 23, at 221.

193. Id. at 221-22. 
however, "vigorously" disagreed, arguing, based on his own reading of the available intelligence, that Robow was leading a Shabab faction that actually opposed attacking the United States. ${ }^{194}$ Reportedly, the NSC's DeRosa "brushed Koh off, telling him she understood his policy concerns," to which Koh "pushed back hard," arguing that it was not simply a matter of policy, but law. ${ }^{195}$ Koh reportedly ended his argument by "slowly and emphatically" telling the NSC's DeRosa that '[t]he State Department legal adviser, for the record, believes this killing would be unlawful." 196

The central issue is whether, in fact, an adequate "record" of such crucial debates, dissents, and justifications is being both created and preserved. If the law does not compel such recordkeeping - and in the executive branch's view the law currently does not-then that leaves political incentives alone, which discourage maintaining such records. The publicly available account of the NSC debate over Robow, for example, noted the implications of Koh's objection. "The White House hated dissent among the lawyers. If word leaked that Robow was killed against the explicit advice of the State Department, it could cause a scandal." 197

Moreover, while Robow was reportedly not targeted, reasons abound for officials not to maintain documentation of approved and executed strikes that might result in "mistakes" or constitute unlawful overstepping. While, in theory, the executive branch ought to have internal incentives compelling the maintenance of a detailed record to enable the systematic examination and correction of errors, misidentifications, and reliance on faulty intelligence, the courts have noted that executive agencies instead "have a built-in incentive to destroy records relating to "mistakes." 198 This reality, combined with the executive branch's vigorous argument defending the President's claimed authority to destroy NSC records relating to drone killings "that neither the Archivist, nor Congress, nor the court may veto," 199 presents a serious risk to long-term accountability.

Courts have expressed frustration at their own lack of oversight over an executive killing program that appears "on its face incompatible with our Constitution," 200 and Congress has protested a lack of executive branch transparency about the program. Both are in a position to create a meaningful check on the Executive and ensure a measure of accountability simply by

194. Id. at 222 .

195. Id. (emphasis added).

196. Id. (emphasis added).

197. Id.

198. Am. Friends Serv. Comm. v. Webster, 720 F.2d 29, 41 (D.C. Cir. 1983).

199. Reply in Support of Defendant's Motion To Dismiss for Failure to State a Claim at 7, Main Street Legal Servs., Inc. v. Nat'l Sec. Council, 2013 WL 3094836 (E.D.N.Y. June 7, 2013) (No. 13-cv-00948).

200. New York Times, v. U.S. Dep't of Justice, 915 F. Supp. 2d 508, 515-16 (S.D.N.Y. 2013), aff'd in part, rev'd in part, 2014 WL 1569514 (2d Cir. Apr. 21, 2014). 
reasserting the application of the FOIA and the FRA to the NSC, as originally intended.

The grandfather of Abdulrahman al-Awlaqi, the U.S. teenager whose drone killing government officials privately admitted was an "outrageous mistake," "201 asked in a 2013 New York Times op-ed: "The government has killed a 16-year-old American boy. Shouldn't it at least have to explain why?"202 The answer to that question is currently classified. It is a modest proposition that the government should be legally required to ensure the existence and preservation of relevant records so that the answer can one day be known. 